\title{
The UK Environmental Change Network datasets - integrated and co-located data for long-term environmental research (1993-2015)
}

\author{
Susannah Rennie ${ }^{1}$, Chris Andrews ${ }^{2}$, Sarah Atkinson ${ }^{3}$, Deborah Beaumont ${ }^{4}$, Sue Benham ${ }^{5}$, \\ Vic Bowmaker ${ }^{6}$, Jan Dick ${ }^{2}$, Bev Dodd ${ }^{1}$, Colm McKenna $^{7}$, Denise Pallett ${ }^{8}$, Rob Rose ${ }^{1}$, \\ Stefanie M. Schäfer ${ }^{8}$, Tony Scott $^{9}$, Carol Taylor ${ }^{10}$, and Helen Watson ${ }^{10}$ \\ ${ }^{1}$ UK Centre for Ecology and Hydrology, Lancaster Environment Centre, \\ Library Avenue, Bailrigg, Lancaster, LA1 4AP, UK \\ ${ }^{2}$ UK Centre for Ecology and Hydrology, Bush Estate, Penicuik, Edinburgh, Midlothian, EH26 0QB, UK \\ ${ }^{3}$ Defence Science and Technology Laboratory, Dstl Porton, Porton Down, Salisbury, Wiltshire, SP4 0JQ, UK \\ ${ }^{4}$ Rothamsted Research, North Wyke, Okehampton, Devon, EX20 2SB, UK \\ ${ }^{5}$ Forest Research, CESB, Alice Holt Lodge, Wrecclesham, Farnham, Surrey, GU10 4LH, UK \\ ${ }^{6}$ Cyfoeth Naturiol Cymru - Natural Resources Wales, Maes-y-Ffynnon, \\ Penrhosgarnedd, Bangor, Gwynedd, LL57 2DW, UK \\ ${ }^{7}$ Agri-Food and Biosciences Institute, Newforge Lane, Belfast, BT9 5PX, UK \\ ${ }^{8}$ UK Centre for Ecology and Hydrology, Maclean Building, Crowmarsh Gifford, \\ Wallingford, Oxon, OX10 8BB, UK \\ ${ }^{9}$ Rothamsted Research, West Common, Harpenden, Herts, AL5 2JQ, UK \\ ${ }^{10}$ The James Hutton Institute, Craigiebuckler, Aberdeen, AB15 8QH, UK
}

Correspondence: Susannah Rennie (srennie@ceh.ac.uk)

Received: 8 May 2019 - Discussion started: 12 June 2019

Revised: 27 November 2019 - Accepted: 29 November 2019 - Published: 14 January 2020

\begin{abstract}
Long-term datasets of integrated environmental variables, co-located together, are relatively rare. The UK Environmental Change Network (ECN) was launched in 1992 and provides the UK with its only long-term integrated environmental monitoring and research network for the assessment of the causes and consequences of environmental change. Measurements, covering a wide range of physical, chemical, and biological "driver" and "response" variables are made in close proximity at ECN terrestrial sites using protocols incorporating standard quality control procedures. This paper describes the datasets (there are 19 published ECN datasets) for these co-located measurements, containing over 20 years of data (1993-2015). The data and supporting documentation are freely available from the NERC Environmental Information Data Centre under the terms of the Open Government Licence using the following DOIs.
\end{abstract}

Meteorology

- Meteorology: https://doi.org/10.5285/fc9bcd1c-e3fc-4c5a-b569-2fe62d40f2f5 (Rennie et al., 2017a)

Biogeochemistry

- Atmospheric nitrogen chemistry: https://doi.org/10.5285/baf51776-c2d0-4e57-9cd3-30cd6336d9cf (Rennie et al., 2017b)

- Precipitation chemistry: https://doi.org/10.5285/18b7c387-037d-4949-98bc-e8db5ef4264c (Rennie et al., 2017c)

- Soil solution chemistry: https://doi.org/10.5285/b330d395-68f2-47f1-8d59-3291dc02923b (Rennie et al., 2017d) 
- Stream water chemistry: https://doi.org/10.5285/fd7ca5ef-460a-463c-ad2b-5ad48bb4e22e (Rennie et al., 2017e)

- Stream water discharge: https://doi.org/10.5285/8b58c86b-0c2a-4d48-b25a-7a0141859004 (Rennie et al., 2017f)

Invertebrates

- Moths: https://doi.org/10.5285/a2a49f47-49b3-46da-a434-bb22e524c5d2 (Rennie et al., 2017g)

- Butterflies: https://doi.org/10.5285/5aeda581-b4f2-4e51-b1a6-890b6b3403a3 (Rennie et al., 2017h)

- Carabid beetle: https://doi.org/10.5285/8385f864-dd41-410f-b248-028f923cb281 (Rennie et al., 2017i)

- Spittle bugs: https://doi.org/10.5285/aff433be-0869-4393-b765-9e6faad2a12b (Rennie et al., 2018)

Vegetation

- Baseline: https://doi.org/10.5285/a7b49ac1-24f5-406e-ac8f-3d05fb583e3b (Rennie et al., 2016a)

- Coarse grain: https://doi.org/10.5285/d349babc-329a-4d6e-9eca-92e630e1be3f (Rennie et al., 2016b)

- Woodland: https://doi.org/10.5285/94aef007-634e-42db-bc52-9aae86adbd33 (Rennie et al., 2017j)

- Fine grain: https://doi.org/10.5285/b98efec8-6de0-4e0c-85dc-fe4cdf01f086 (Rennie et al., 2017k)

Vertebrates

- Frogs: https://doi.org/10.5285/4d8c7dd9-8248-46ca-b988-c1fc38e51581 (Rennie et al., 20171)

- Birds (Breeding bird survey): https://doi.org/10.5285/5886c3ba-1fa5-49c0-8da8-40e69a10d2b5 (Rennie et al., 2017m)

- Birds (Common bird census): https://doi.org/10.5285/8582a02c-b28c-45d2-afa1-c1e85fba023d (Rennie et al., 2017n)

- Bats: https://doi.org/10.5285/2588ee91-6cbd-4888-86fc-81858d1bf085 (Rennie et al., 2017o)

- Rabbits and deer: https://doi.org/10.5285/0be0aed3-f205-4f1f-a65d-84f8cfd8d50f (Rennie et al., 2017p)

\section{Introduction}

The assessment of environmental change requires an understanding of how ecosystems function, how they respond to a range of pressures and how resilient they are to such changes. To make these assessments, precise and consistent measurements repeated over long periods of time are needed (Sier and Monteith, 2016a). Ideally, these measurements should also be co-located to provide opportunities to directly link pressures and responses. This type of monitoring effort requires sustained funding (longer than usual research grants) and a clear long-term vision. Consequently, robust long-term environmental research networks are relatively rare.

The Environmental Change Network (ECN), launched in 1992, is the UK's long-term integrated environmental monitoring and research network (Environmental Change Network, 2019). The ECN collects information on a broad baseline of integrated environmental information. The programme also provides more immediate information about trends and early warning of environmental extremes that may directly influence environmental policy. The ECN programme is sponsored by a consortium of 14 UK Government departments and agencies (see Acknowledgements), who contribute to the programme through funding either site monitoring or network co-ordination activities. Internationally, the ECN is formally recognised as the UK node of a global system of long-term environmental research networks (LTER-Europe, Mirtl, 2010 and ILTER, Kim, 2006; Mirtl et al., 2018). For the period covered by the published datasets, there were 12 terrestrial sites in the network (see Fig. 1), selected to cover the main range of environmental conditions present in the UK (see Table 1). Links to site descriptions on the ECN website and on DEIMS-SDR, an information management system that allows discovery of long-term ecosystem research sites around the globe (Wohner, 2019), are included in Table 1 . The majority of these sites have been collecting data since at least 1993, meaning over 20 years of ECN data are now available. However, many of the sites were chosen because they had a long history of environmental monitoring and thus additional pre-ECN data available.

The monitoring programme includes a wide range of physical, chemical and biological "driver" and "response" variables, identified by experts in the field as being important for the assessment of environmental change (see Table 2). A Statistical and Technical Advisory Group met regularly to review ECN monitoring activities. These measurements are 
Table 1. ECN terrestrial sites.

\begin{tabular}{|c|c|c|c|c|c|}
\hline $\begin{array}{l}\text { Site } \\
\text { (ECN site code) }\end{array}$ & $\begin{array}{l}\text { Site description (links to the ECN website } \\
\text { and DEIMS-SDR, last access: } 8 \text { January 2020) }\end{array}$ & Location & $\begin{array}{l}\text { Altitudinal } \\
\text { range } \\
\text { (m a.s.1.) }\end{array}$ & $\begin{array}{l}\text { Area } \\
\text { (ha) }\end{array}$ & Site type \\
\hline Alice Holt (T09) & $\begin{array}{l}\text { http://data.ecn.ac.uk/sites/ecnsites.asp?site=T09 } \\
\text { https://deims.org/d47ec839-5d20-4315-9f88-1e9edbab22e8 }\end{array}$ & $\begin{array}{l}51^{\circ} 9^{\prime} 16.46^{\prime \prime} \mathrm{N} \\
0^{\circ} 51^{\prime} 47.58^{\prime \prime} \mathrm{W}\end{array}$ & $110-125$ & 850 & Woodland \\
\hline Drayton (T01) & $\begin{array}{l}\text { http://data.ecn.ac.uk/sites/ecnsites.asp?site=T01 } \\
\text { https://deims.org/00eb83ef-c965-462d-8022-7f7ff75ccd14 }\end{array}$ & $\begin{array}{l}52^{\circ} 11^{\prime} 37.95^{\prime \prime} \mathrm{N} \\
1^{\circ} 45^{\prime} 51.95^{\prime \prime} \mathrm{W}\end{array}$ & $320-1110$ & 1000 & $\begin{array}{l}\text { Lowland grass- } \\
\text { land/agricultural } \\
\text { (data collection } \\
\text { ceased at this } \\
\text { site at the end of } \\
\text { 2013) }\end{array}$ \\
\hline Cairngorms (T12) & $\begin{array}{l}\text { http://data.ecn.ac.uk/sites/ecnsites.asp?site=T12 } \\
\text { https://deims.org/5a04fee1-42aa-47e9-abfc-043a3eda12ac }\end{array}$ & $\begin{array}{l}57^{\circ} 6^{\prime} 58.84^{\prime \prime} \mathrm{N} \\
43^{\circ} 49^{\prime} 46.98^{\prime \prime} \mathrm{W}\end{array}$ & $40-80$ & 190 & $\begin{array}{l}\text { Upland } \\
\text { moor/mountain }\end{array}$ \\
\hline Glensaugh (T02) & $\begin{array}{l}\text { http://data.ecn.ac.uk/sites/ecnsites.asp?site=T02 } \\
\text { https://deims.org/1c4d454d-0c00-49f9-a7fe-3a3e596c3648 }\end{array}$ & $\begin{array}{l}56^{\circ} 54^{\prime} 33.36^{\prime \prime} \mathrm{N} \\
2^{\circ} 33^{\prime} 12.14^{\prime \prime} \mathrm{W}\end{array}$ & $137-487$ & 1125 & $\begin{array}{l}\text { Upland } \\
\text { moor/mountain } \\
\text { with native } \\
\text { mixed pine } \\
\text { wood }\end{array}$ \\
\hline Hillsborough (T03) & $\begin{array}{l}\text { http://data.ecn.ac.uk/sites/ecnsites.asp?site=T03 } \\
\text { https://deims.org/371c5259-6f38-4aa7-9517-c56f608c62cc }\end{array}$ & $\begin{array}{l}54^{\circ} 27^{\prime} 12.24^{\prime \prime} \mathrm{N} \\
6^{\circ} 4^{\prime} 41.26^{\prime \prime} \mathrm{W}\end{array}$ & $110-170$ & 400 & $\begin{array}{l}\text { Lowland grass- } \\
\text { land/agricultural }\end{array}$ \\
\hline $\begin{array}{l}\text { Moor House - Up- } \\
\text { per Teesdale (T04) }\end{array}$ & $\begin{array}{l}\text { http://data.ecn.ac.uk/sites/ecnsites.asp?site=T04 } \\
\text { https://deims.org/bf78c96f-0763-4b31-b1a6-6eccef19edd1 }\end{array}$ & $\begin{array}{l}54^{\circ} 41^{\prime} 42.15^{\prime \prime} \mathrm{N} \\
2^{\circ} 23^{\prime} 16.26^{\prime \prime} \mathrm{W}\end{array}$ & $290-848$ & 7500 & $\begin{array}{l}\text { Upland } \\
\text { moor/mountain }\end{array}$ \\
\hline North Wyke (T05) & $\begin{array}{l}\text { http://data.ecn.ac.uk/sites/ecnsites.asp?site=T05 } \\
\text { https://deims.org/4fbe4bf9-e342-4412-8f0c-c75aff08a8ca }\end{array}$ & $\begin{array}{l}50^{\circ} 46^{\prime} 54.96^{\prime \prime} \mathrm{N} \\
3^{\circ} 55^{\prime} 4.10^{\prime \prime} \mathrm{W}\end{array}$ & $120-180$ & 250 & $\begin{array}{l}\text { Lowland grass- } \\
\text { land/agricultural }\end{array}$ \\
\hline Porton Down (T10) & $\begin{array}{l}\text { http://data.ecn.ac.uk/sites/ecnsites.asp?site=T10 } \\
\text { https://deims.org/0f05a86f-0f7a-4b81-8268-6818a6064428 }\end{array}$ & $\begin{array}{l}51^{\circ} 7^{\prime} 37.83^{\prime \prime} \mathrm{N} \\
1^{\circ} 38^{\prime} 23.46^{\prime \prime} \mathrm{W}\end{array}$ & $100-172$ & 1227 & $\begin{array}{l}\text { Lowland grass- } \\
\text { land }\end{array}$ \\
\hline Rothamsted (T06) & $\begin{array}{l}\text { http://data.ecn.ac.uk/sites/ecnsites.asp?site=T06 } \\
\text { https://deims.org/cb340d4c-e6e5-465a-b0cb-d6c613fa5541 }\end{array}$ & $\begin{array}{l}51^{\circ} 48^{\prime} 12.33^{\prime \prime} \mathrm{N} \\
0^{\circ} 22^{\prime} 21.66^{\prime \prime} \mathrm{W}\end{array}$ & $94-134$ & 330 & $\begin{array}{l}\text { Lowland grass- } \\
\text { land/agricultural }\end{array}$ \\
\hline Sourhope (T07) & $\begin{array}{l}\text { http://data.ecn.ac.uk/sites/ecnsites.asp?site=T07 } \\
\text { https://deims.org/125d4667-0fae-418d-88ff-7d9930809d12 }\end{array}$ & $\begin{array}{l}55^{\circ} 29^{\prime} 23.47^{\prime \prime} \mathrm{N} \\
2^{\circ} 12^{\prime} 43.32^{\prime \prime} \mathrm{W}\end{array}$ & $200-601$ & 1119 & $\begin{array}{l}\text { Upland } \\
\text { moor/mountain }\end{array}$ \\
\hline Wytham (T08) & $\begin{array}{l}\text { http://data.ecn.ac.uk/sites/ecnsites.asp?site=T08 } \\
\text { https://deims.org/16dcd0c3-a114-412c-9f01-8c1af292ba69 }\end{array}$ & $\begin{array}{l}51^{\circ} 46^{\prime} 52.86^{\prime \prime} \mathrm{N} \\
1^{\circ} 20^{\prime} 9.81^{\prime \prime} \mathrm{W}\end{array}$ & $60-165$ & 770 & $\begin{array}{l}\text { Woodland/ agri- } \\
\text { cultural }\end{array}$ \\
\hline $\begin{array}{l}\text { Yr Wyddfa (Snow- } \\
\text { don) (T11) }\end{array}$ & $\begin{array}{l}\text { http://data.ecn.ac.uk/sites/ecnsites.asp?site=T11 } \\
\text { https://deims.org/8b5da977-eed8-459f-b663-f3835aa0b356 }\end{array}$ & $\begin{array}{l}53^{\circ} 4^{\prime} 28.38^{\prime \prime} \mathrm{N} \\
4^{\circ} 2^{\prime} 0.64^{\prime \prime} \mathrm{W}\end{array}$ & $298-1085$ & 700 & $\begin{array}{l}\text { Upland } \\
\text { moor/mountain }\end{array}$ \\
\hline
\end{tabular}

made in close proximity at each site, using standard protocols incorporating standard quality control procedures (Sykes and Lane, 1996).

Data are managed by the ECN Data Centre, which has an integrated information system (Rennie, 2016) that stores all data and metadata collected by the networks which supply data to it. These data are held in standardised structures in order to support the cross-disciplinary analyses necessary for environmental change research. An associated summary database consists of monthly, quarterly and/or annual summaries of these data using summary statistics appropriate to each measurement, as advised by experts. These summary data can be explored through data visualisation interfaces available on the website (ECN Data Centre, 2019). The database uses the Oracle relational database management system with links to Arc GIS for spatial data handling. Data were regularly sent in from sites and were quality-assured be- fore being lodged in the database (information about quality control is in Sect. 4).

This paper describes the datasets for the high-frequency, co-located ECN measurements. There are 19 published datasets (Table 2), containing over 20 years of data (19932015), covering biological, meteorological and biogeochemical measurements (Rennie et al., 2016a, b, 2017a-p, 2018). They are hosted by the NERC Environmental Information Data Centre and are available to users under the Open Government Licence.

\section{Methods}

ECN measurements are co-ordinated and standardised across sites according to published protocol procedures (Sykes and Lane, 1996). The protocol documents are included in the supporting documentation provided alongside every data down- 
Table 2. ECN datasets.

\begin{tabular}{|c|c|c|c|}
\hline $\begin{array}{l}\text { Measurement } \\
\text { (ECN measurement } \\
\text { code) }\end{array}$ & Frequency of data collection & Variable/s recorded & DOI (citation) \\
\hline Meteorology (MA) & $\begin{array}{l}\text { Hourly summaries calculated from } \\
5 \mathrm{~s} \text { samplings }\end{array}$ & See Table 3 & $\begin{array}{l}\text { https://doi.org/10.5285/fc9bcd1c-e3fc-4c5a- } \\
\text { b569-2fe62d40f2f5 (Rennie et al., 2017a) }\end{array}$ \\
\hline $\begin{array}{l}\text { Atmospheric nitrogen } \\
\text { (AN) }\end{array}$ & Fortnightly & See Table 4 & $\begin{array}{l}\text { https://doi.org/10.5285/baf51776-c2d0-4e57- } \\
\text { 9cd3-30cd6336d9cf (Rennie et al., 2017b) }\end{array}$ \\
\hline $\begin{array}{l}\text { Precipitation chemistry } \\
\text { (PC) }\end{array}$ & Weekly & See Table 5 & $\begin{array}{l}\text { https://doi.org/10.5285/18b7c387-037d-4949- } \\
\text { 98bc-e8db5ef4264c (Rennie et al., 2017c) }\end{array}$ \\
\hline $\begin{array}{l}\text { Soil solution } \\
\text { (SS) }\end{array}$ & Fortnightly & See Table 5 & $\begin{array}{l}\text { https://doi.org/10.5285/b330d395-68f2-47f1- } \\
\text { 8d59-3291dc02923b (Rennie et al., 2017d) }\end{array}$ \\
\hline $\begin{array}{l}\text { Surface water chemistry } \\
\text { (WC) }\end{array}$ & Weekly & See Table 5 & $\begin{array}{l}\text { https://doi.org/10.5285/fd7ca5ef-460a-463c- } \\
\text { ad2b-5ad48bb4e22e (Rennie et al., 2017e) }\end{array}$ \\
\hline $\begin{array}{l}\text { Surface water discharge } \\
\text { (WD) }\end{array}$ & $\begin{array}{l}15 \mathrm{~min} \text { averages calculated from } \\
10 \mathrm{~s} \text { samplings of stage height }\end{array}$ & $\begin{array}{l}\text { Stage }(\mathrm{m}) \\
\text { Discharge }\left(\mathrm{m}^{3} \mathrm{~s}^{-1}\right)\end{array}$ & $\begin{array}{l}\text { https://doi.org/10.5285/8b58c86b-0c2a-4d48- } \\
\text { b25a-7a0141859004 (Rennie et al., 2017f) }\end{array}$ \\
\hline Moth (IM) & Nightly; weekly at remote sites & $\begin{array}{l}\text { Count of each species } \\
\text { trapped }\end{array}$ & $\begin{array}{l}\text { https://doi.org/10.5285/a2a49f47-49b3-46da- } \\
\text { a434-bb22e524c5d2 (Rennie et al., 2017g) }\end{array}$ \\
\hline Butterfly (IB) & $\begin{array}{l}\text { Weekly between April and Septem- } \\
\text { ber - dependant on weather condi- } \\
\text { tions }\end{array}$ & $\begin{array}{l}\text { Count of each species } \\
\text { observed }\end{array}$ & $\begin{array}{l}\text { https://doi.org/10.5285/5aeda581-b4f2-4e51- } \\
\text { b1a6-890b6b3403a3 (Rennie et al., 2017h) }\end{array}$ \\
\hline Carabid beetles (IG) & Fortnightly & $\begin{array}{l}\text { Count of each species } \\
\text { trapped }\end{array}$ & $\begin{array}{l}\text { https://doi.org/10.5285/8385f864-dd41-410f- } \\
\text { b248-028f923cb281 (Rennie et al., 2017i) }\end{array}$ \\
\hline Spittle bugs (IS) & Annual & $\begin{array}{l}\text { Count of each } \\
\text { species and colour } \\
\text { morph }\end{array}$ & $\begin{array}{l}\text { https://doi.org/10.5285/aff433be-0869-4393- } \\
\text { b765-9e6faad2a12b (Rennie et al., 2018) }\end{array}$ \\
\hline Baseline vegetation (VB) & One-off survey & Species presence & $\begin{array}{l}\text { https://doi.org/10.5285/a7b49ac1-24f5-406e- } \\
\text { ac8f-3d05fb583e3b (Rennie et al., 2016a) }\end{array}$ \\
\hline $\begin{array}{l}\text { Coarse-grain vegetation } \\
\text { (VC) }\end{array}$ & Every 9 years & Species presence & $\begin{array}{l}\text { https://doi.org/10.5285/d349babc-329a-4d6e- } \\
\text { 9eca-92e630e1be3f (Rennie et al., 2016b) }\end{array}$ \\
\hline $\begin{array}{l}\text { Woodland vegetation } \\
\text { (VW) }\end{array}$ & $\begin{array}{l}\text { Every } 9 \text { years }- \text { diameter at breast } \\
\text { height }(\mathrm{dbh}) \text { recorded every } 3 \text { years }\end{array}$ & See Table 6 & $\begin{array}{l}\text { https://doi.org/10.5285/94aef007-634e-42db- } \\
\text { bc52-9aae86adbd33 (Rennie et al., 2017j) }\end{array}$ \\
\hline $\begin{array}{l}\text { Fine-grain vegetation } \\
\text { (VF) }\end{array}$ & $\begin{array}{l}\text { Every } 3 \text { years }- \text { some sites per- } \\
\text { formed this annually }\end{array}$ & Species presence & $\begin{array}{l}\text { https://doi.org/10.5285/b98efec8-6de0-4e0c- } \\
\text { 85dc-fe4cdf01f086 (Rennie et al., 2017k) }\end{array}$ \\
\hline Frog $(\mathrm{BF})$ & Annual & See Table 7 & $\begin{array}{l}\text { https://doi.org/10.5285/4d8c7dd9-8248-46ca- } \\
\text { b988-c1fc38e51581 (Rennie et al., 2017l) }\end{array}$ \\
\hline $\begin{array}{l}\text { Breeding Bird Survey } \\
\text { (BB) }\end{array}$ & Twice a year & $\begin{array}{l}\text { Count of each species } \\
\text { observed }\end{array}$ & $\begin{array}{l}\text { https://doi.org/10.5285/5886c3ba-1fa5-49c0- } \\
\text { 8da8-40e69a10d2b5 (Rennie et al., 2017m) }\end{array}$ \\
\hline $\begin{array}{l}\text { Common Bird Census } \\
\text { (CBC) }\end{array}$ & $\begin{array}{l}\text { Annual (variable date ranges for } \\
\text { sites) }\end{array}$ & $\begin{array}{l}\text { Count of each species } \\
\text { observed and/or nests } \\
\text { observed }\end{array}$ & $\begin{array}{l}\text { https://doi.org/10.5285/8582a02c-b28c-45d2- } \\
\text { afa1-c1e85fba023d (Rennie et al., 2017n) }\end{array}$ \\
\hline Bat (BA) & Four times a year & $\begin{array}{l}\text { Count of each species } \\
\text { observed } \\
\text { Behaviour }\end{array}$ & $\begin{array}{l}\text { https://doi.org/10.5285/2588ee91-6cbd-4888- } \\
\text { 86fc-81858d1bf085 (Rennie et al., 2017o) }\end{array}$ \\
\hline Rabbit and deer (BU) & Twice a year & $\begin{array}{l}\text { Count of the dropping } \\
\text { of each species }\end{array}$ & $\begin{array}{l}\text { https://doi.org/10.5285/0be0aed3-f205-4f1f- } \\
\text { a65d-84f8cfd8d50f (Rennie et al., 2017p) }\end{array}$ \\
\hline
\end{tabular}




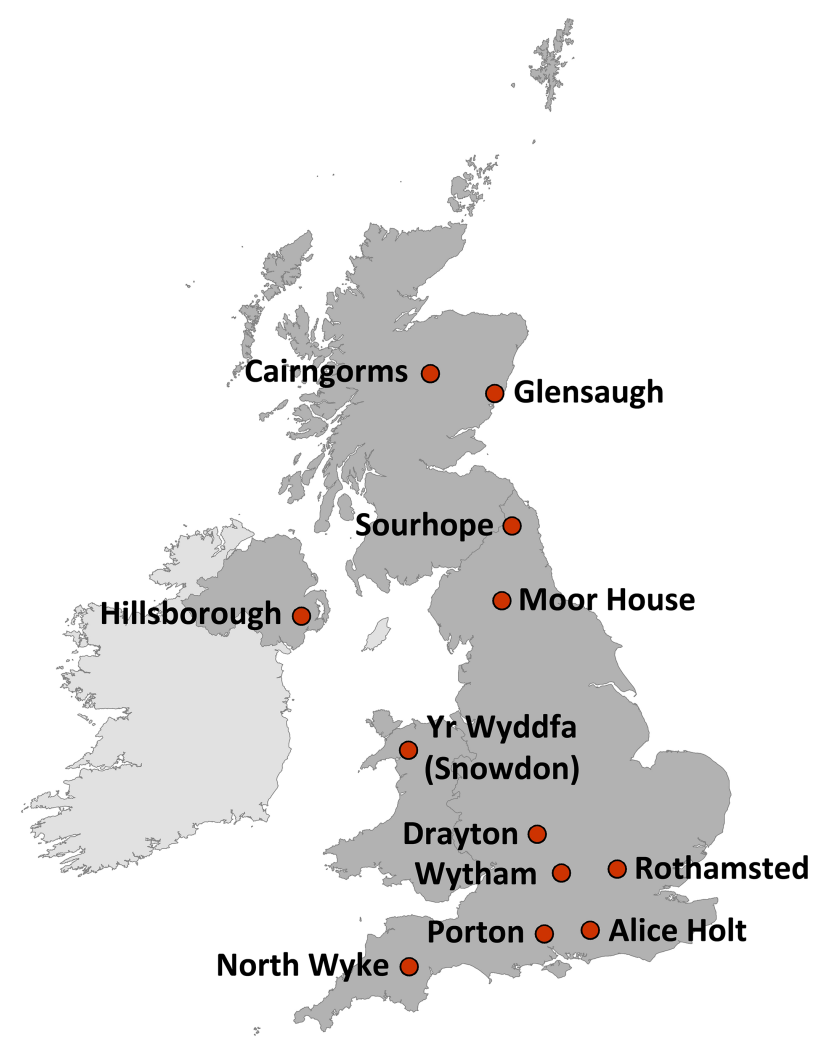

Figure 1. Locations of the ECN terrestrial sites.

load. The protocols are designed to ensure consistency in methods and data handling over time and across the ECN's sites. Sites were visited on the same day each week, preferably on a Wednesday, to synchronise sampling, within the site and across the network.

The protocol documents detail quality control procedures, e.g. correct handling of equipment and samples, maintenance schedules, and calibration specifications, as well as unambiguous instructions for measurement and data handling. Data requirements are an integral part of these protocols and include specifications of variables, units, reporting precisions, dimensions, resolutions, reference systems and quality assurance procedures. These specifications, together with as much information as possible about likely user requirements, were used in the design of the database and the construction of standard formats for data transfer and standard field forms for each dataset. Where available, existing data capture methodologies were used (e.g. the Rothamsted light trap network, part of the Rothamsted Insect Survey, 2019) to maintain compatibility with other sectoral networks.

At each site, an area of 1 ha $\left(10000 \mathrm{~m}^{2}\right)$ was selected and permanently marked. This is called the target sampling site (TSS), and destructive sampling within it was kept to a minimum. Many of the measurements are co-located within the TSS. Dispersed monitoring protocols (e.g. vegetation) also include plots within the TSS. The TSS was chosen to be rep- resentative of the predominant vegetation, soil and management of the site.

Some protocols (Sect. 2.15 to 2.19) have not been measured at all sites or have had varied uptake at sites over time, limiting their use for cross-site comparison. In addition, some protocols are designed as national-scale surveys, thus they have limited use for assessment of trends at individual sites. These limitations are discussed with each individual dataset. The methods for data collection for the 19 published ECN datasets (1993-2015) are summarised below.

\subsection{Meteorology}

Automatic weather stations (AWSs) were installed at all ECN terrestrial sites and situated in accordance with British Meteorological Office site requirements (Meteorological Office, 1982). The AWS was ideally located on, or within $500 \mathrm{~m}$ of, the TSS. The layout of the meteorological enclosure is provided in Fig. 2. Full details for the procedure for installing an AWS are provided in the protocol document (Burt and Johnson, 1996), but the instruments were fixed to two crossarms - one at $2 \mathrm{~m}$ above ground level and oriented east-west and the other a $1 \mathrm{~m}$ a.g.l. and oriented north-south. The wind vane and anemometer were located on the upper cross-arm and the air temperature and radiation sensors on the lower cross-arm. A number of the sites also had either a manual meteorological station (referred to as MM in Fig. 2) or a second AWS to quality check the data. In addition, the majority of sites have operated more than one AWS in the same location, e.g. when kit is replaced (see Sect. 3.1 for details on how this is recorded in the dataset). All ECN AWS instruments were subject to regular (normally annual or biannual) professional calibration checks by external contractors. The data are hourly summaries calculated from $5 \mathrm{~s}$ samplings and the variables recorded are listed in Table 3. Full operating procedures are provided in the protocol document (Burt and Johnson, 1996), which is included in the supporting documentation provided alongside the data download (called MA.pdf).

\subsection{Atmospheric nitrogen}

Passive diffusion tubes were used to measure the concentration of nitrogen dioxide $\left(\mathrm{NO}_{2}\right)$ at all ECN terrestrial sites. They were attached to a post at a height of $1.5 \mathrm{ma}$ a.g.1. in the meteorological enclosure (Fig. 2). As a control measure, blank tubes were also transported to the site but were not exposed on arrival. The blank tubes were returned to the laboratory the same day, stored in a refrigerator and analysed in the lab alongside the experimental tubes. In the early years of the ECN, the diffusion tubes were assembled and analysed locally, but these were replaced at some sites by commercially made tubes manufactured and analysed by Gradko Ltd. Comparability tests were conducted when this switch was made. The samples were collected fortnightly and the variables recorded are listed in Table 4. Full operating proce- 


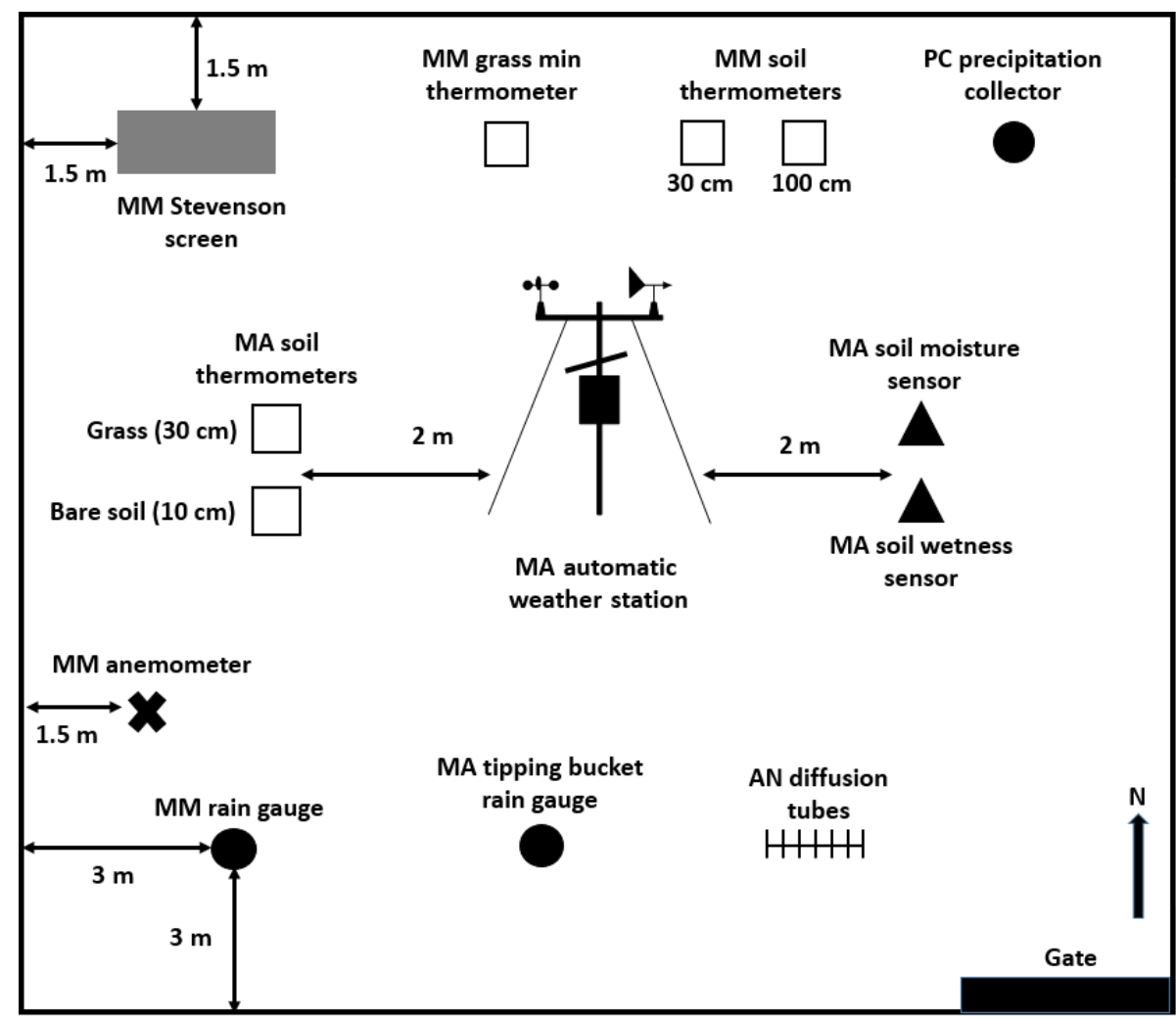

Figure 2. ECN meteorological enclosure (MA: automatic weather station; PC: precipitation chemistry; AN: atmospheric nitrogen; MM: manual meteorology).

Table 3. Meteorological variables.

\begin{tabular}{|c|c|c|}
\hline Name in dataset & Description & Units \\
\hline ALBGRD & Albedo ground (average) & $\mathrm{W} \mathrm{m}^{-2}$ \\
\hline ALBSKY & Albedo sky (average) & $\mathrm{W} \mathrm{m}^{-2}$ \\
\hline DRYTMP & Dry bulb temperature (average) & ${ }^{\circ} \mathrm{C}$ \\
\hline DRTYMP_RH & Dry bulb temperature within the relative humidity sensor (average) & ${ }^{\circ} \mathrm{C}$ \\
\hline NETRAD & Net radiation (average) & $\mathrm{W} \mathrm{m}^{-2}$ \\
\hline RAIN & Rainfall (total) & $\mathrm{mm}$ \\
\hline RH & Relative humidity (average) & $\%$ \\
\hline SOLAR & Solar radiation (average) & $\mathrm{W} \mathrm{m}^{-2}$ \\
\hline STMP10 & Soil temperature at $10 \mathrm{~cm}$ (average) & ${ }^{\circ} \mathrm{C}$ \\
\hline STMP30 & Soil temperature at $30 \mathrm{~cm}$ (average) & ${ }^{\circ} \mathrm{C}$ \\
\hline SURWET & Surface wetness (number of minutes in the hour that surface is wet) & $\min$ \\
\hline SWATER & Soil moisture - gypsum block (average) & bar \\
\hline SWATER_T & Soil moisture - theta probe at $20 \mathrm{~cm}$ (average) & $\%$ \\
\hline SWATER_T10 & Soil moisture - theta probe at $10 \mathrm{~cm}$ (average) & $\%$ \\
\hline SWATER_VWC & Soil moisture - volumetric water content at $20 \mathrm{~cm}$ (average) & $\mathrm{m}^{3} \mathrm{~m}^{-3}$ \\
\hline WDIR & Wind direction (average) & degrees \\
\hline WETTMP & Wet bulb temperature (average) & ${ }^{\circ} \mathrm{C}$ \\
\hline WSPEED & Wind speed (average) & $\mathrm{m} \mathrm{s}^{-1}$ \\
\hline
\end{tabular}


Table 4. Atmospheric chemistry variables.

\begin{tabular}{lll}
\hline Name in dataset & Description & Units \\
\hline WEIGHTNO2 & Weight of $\mathrm{NO}_{2}$ on the mesh & $\mu \mathrm{g}$ \\
NO2 & $\mathrm{NO}_{2}$ concentration & $\mu \mathrm{g} \mathrm{m}^{-3}$ \\
NO2PPB & $\mathrm{NO}_{2}$ concentration & $\mathrm{ppb}$ \\
TDIFF & Exposure time & min \\
Q1-n & Quality code (see Sect. 4) & integer \\
\hline
\end{tabular}

dures are provided in the protocol document (Bojanic, 1996), which is included in the supporting documentation provided alongside the data download (called AN.pdf).

\subsection{Precipitation chemistry}

Bulk (open funnel) precipitation collectors were used to measure the precipitation chemistry at all ECN terrestrial sites. These were situated in the meteorological enclosure (Fig. 2), in an open location away from local sources of contamination (e.g. vehicle tracks or animal houses). Warren Spring Laboratory standard precipitation collectors were used, with the collecting bottle fixed $1.75 \mathrm{~m}$ a.g.l. The collectors were secured by guy ropes or bolted to a concrete base. The collector had a filter to prevent debris falling into the bottle and was kept dark and cool by a jacket. The collecting bottle was changed at the same time each week, and the funnel was replaced or cleaned with deionised water. The volume collected was recorded, and analysis of the samples were made by the analytical laboratories linked to each site. The cost of standardising methods of analysis across all ECN laboratories was prohibitive. Instead, the analytical guidelines (available in supporting documentation available with the data download) list approved techniques for each determinand with their corresponding limits of detection. The sponsoring organisations were responsible for maintaining their own continuity in methods for existing long-term runs of data. Each laboratory practised its own internal quality control, and most participated in national quality assurance schemes. As a quality check, a standard quality control solution was sent to the laboratories that analyse the ECN water samples. This solution was analysed alongside the samples collected in the field. The samples were collected weekly, and the variables recorded are listed in Table 5. Full operating procedures are provided in the protocol document (Adamson and Sykes, 1996), which is included in the supporting documentation provided alongside the data download (called PC.pdf). Operating procedures for handling water samples (Adamson, 1996a) and analytical guidelines (Rowland, 1996) are also provided in the supporting information (called WH.pdf and WAG.pdf).

\subsection{Soil solution chemistry}

Water was collected from soils via suction lysimeters at the majority of ECN terrestrial sites. The lysimeters were installed at two depths within a $10 \mathrm{~m}$ by $10 \mathrm{~m}$ plot on the edge of (but outside) the TSS. Six samplers were installed in the A horizon and six others at the base of the B horizon (or at 10 and $50 \mathrm{~cm}$ if these soil horizons did not exist), ideally on a downslope to avoid debris from soil disturbance. Samplers were emptied and the water volumes collected on the same day each fortnight. A week after sample collection, the samplers were evacuated to 0.5 bar (or 0.7 bar for sites where insufficient soil solution could be collected), thus the water only accumulated over the second week of the fortnightly period. The chemistry of the water collected was analysed by the analytical labs associated with each site. At some sites, particularly in drier months, the volume of water collected may have been very small; in these cases, the samples were discarded or, if possible, combined (only samples from the same horizon were combined) for analysis (see Sect. 3.2 for details on how this is recorded in the dataset). The samples were collected fortnightly and the variables recorded are listed in Table 5. Full operating procedures are provided in the protocol document (Adamson, 1996b), which is included in the supporting documentation provided alongside the data download (called SS.pdf). Operating procedures for handling water samples (Adamson, 1996a) and analytical guidelines (Rowland, 1996) are also provided in the supporting information (called WH.pdf and WAG.pdf).

\subsection{Surface water chemistry}

Dip samples from rivers and streams were collected. This was only done at sites where flowing water was present. Samples were taken at a representative location above a weir; some sites collect samples at multiple locations on the site (indicated by the location code in the dataset). The collecting bottle is rinsed in river water, and a $250 \mathrm{~mL}$ sample of river water is taken. The samples were collected weekly and the variables recorded are listed in Table 5. Full operating procedures are provided in the protocol document (Johnson and Burt, 1996a), which is included in the supporting documentation provided alongside the data download (called WC.pdf). Operating procedures for handling water samples (Adamson, 1996a) and analytical guidelines (Rowland, 1996) are also provided in the supporting information (called WH.pdf and WAG.pdf)

\subsection{Surface water discharge}

Hydrological data from rivers and streams were collected by a logger at sites with a river or stream. Recording of river stage was done by a permanently installed weir, the design of which was determined by the conditions at the site. Data were recorded by a logger. The data are $15 \mathrm{~min}$ averages 
Table 5. Chemical and associated variables (precipitation chemistry, soil solution, surface water chemistry).

\begin{tabular}{|c|c|c|}
\hline Name in dataset & Description & Units \\
\hline ALKY & Alkalinity & $\mathrm{mg} \mathrm{L}^{-1}$ \\
\hline ALUMINIUM & Aluminium & $\mathrm{mg} \mathrm{L}^{-1}$ \\
\hline CALCIUM & Calcium & $\mathrm{mg} \mathrm{L}^{-1}$ \\
\hline CHLORIDE & Chloride & $\mathrm{mg} \mathrm{L}^{-1}$ \\
\hline COLOUR & Absorbance at $436 \mathrm{nM}$ & $\mathrm{nM}$ \\
\hline CONDY & Conductivity & $\mu \mathrm{Scm}^{-1}$ \\
\hline DOC & Dissolved organic carbon & $\mathrm{mg} \mathrm{L}^{-1}$ \\
\hline IRON & Iron & $\mathrm{mg} \mathrm{L}^{-1}$ \\
\hline MAGNESIUM & Magnesium & $\mathrm{mg} \mathrm{L}^{-1}$ \\
\hline NH4N & Ammonium & $\mathrm{mg} \mathrm{L}^{-1}$ \\
\hline NO3N & Nitrate nitrogen & $\mathrm{mg} \mathrm{L}^{-1}$ \\
\hline $\mathrm{PH}$ & $\mathrm{pH}$ & $\mathrm{pH}$ scale $1-14$ \\
\hline PHAQCS & Aquacheck system pH stirred & $\mathrm{pH}$ scale $1-14$ \\
\hline PHAQCU & Aquacheck system $\mathrm{pH}$ unstirred & $\mathrm{pH}$ scale $1-14$ \\
\hline PO4P & Phosphate phosphorus & $\mathrm{mg} \mathrm{L}^{-1}$ \\
\hline POTASSIUM & Potassium & $\mathrm{mg} \mathrm{L}^{-1}$ \\
\hline SO4S & Sulfate sulfur & $\mathrm{mg} \mathrm{L}^{-1}$ \\
\hline SODIUM & Sodium & $\mathrm{mg} \mathrm{L}^{-1}$ \\
\hline TOTALN & Total nitrogen & $\mathrm{mg} \mathrm{L}^{-1}$ \\
\hline TOTALP & Total dissolved phosphorus & $\mathrm{mg} \mathrm{L}^{-1}$ \\
\hline VOLUME & Volume of sample collected (precipitation and soil solution chemistry datasets only) & $\mathrm{mL}$ \\
\hline VACUUM & Residual vacuum at time of sampling (soil solution chemistry dataset only) & bar \\
\hline STAGE & Stage reading of water level (surface water chemistry dataset only) & $\mathrm{mm}$ \\
\hline
\end{tabular}

calculated from $10 \mathrm{~s}$ samplings of stage height and the variables recorded are listed in Table 2. Full operating procedures are provided in the protocol document (Johnson and Burt, 1996b), which is included in the supporting documentation provided alongside the data download (called WD.pdf).

\subsection{Moths}

Light traps were used to sample moths (Macrolepidoptera) at the majority of the ECN terrestrial sites using the Rothamsted Insect Survey method (Rothamsted Insect Survey, 2019) at the majority of the ECN terrestrial sites. Where possible, the light trap was sheltered by vegetation and placed away from artificial light sources, in a location that was convenient for daily emptying. The traps require a continuous power supply so this often determined their location. Ideally, the traps were emptied daily throughout the year, but when this was not possible (e.g. for more remote sites or at the weekend) samples could accumulate. Samples from the sites were identified by a single expert contracted by the ECN. The data are stored within the Rothamsted Insect Survey database, as well as in the ECN database. A count of each species trapped was recorded. Full operating procedures are provided in the protocol document (Woiwod, 1996a), which is included in the supporting documentation provided alongside the data download (called IM.pdf).

\subsection{Butterflies}

Butterfly species were recorded on a fixed transect (which was divided into a maximum of 15 sections) at the majority of the ECN terrestrial sites. The transect was chosen to be broadly representative of the site and include areas under different management regimes. The length of the transect was dependant on the local conditions at the site. The national Butterfly Monitoring Scheme methodology was used (UK Butterfly Monitoring Scheme, 2019). The transect was walked at an even pace and the number of butterflies that were seen flying within or passing through an imaginary box ( $5 \mathrm{~m}$ wide, $5 \mathrm{~m}$ high and $5 \mathrm{~m}$ in front of the observer) were recorded. Sampling took place when the temperature was between 13 and $17^{\circ} \mathrm{C}$ if sunshine was at least $60 \%$. However, if the temperature was above $17^{\circ} \mathrm{C}\left(15^{\circ} \mathrm{C}\right.$ at more northerly sites), recording could be carried out in any conditions, providing it was not raining. Transects were walked weekly between 1 April and 29 September, providing the meteorological conditions were met. A count of each species observed was recorded. Full operating procedures are provided in the protocol document (Woiwod, 1996b), which is included in the supporting documentation provided alongside the data download (called IB.pdf). 


\subsection{Carabid beetles}

Pitfall traps were used to collect carabid beetles (Carabidae) at the majority of the ECN terrestrial sites. A total of 30 traps were set, divided between three transects, in or adjacent to the TSS and in areas representing different habitats where possible. The traps were polypropylene, with a $7.5 \mathrm{~cm}$ diameter and $10 \mathrm{~cm}$ depth, and were filled with ethylene glycol preservative. They were buried with the top of the trap flush with the soil surface. The traps were set $10 \mathrm{~m}$ apart along the transect. A wire netting cage made from chicken wire was attached to the rim of the trap to reduce the number of small mammals inadvertently caught. Each trap also had a cover to help prevent rain flooding the traps and to reduce bird interference. Samples were analysed by a local taxonomic expert. The samples were collected fortnightly (between May and the end of October). A count of each species trapped was recorded. Full operating procedures are provided in the protocol document (Woiwod and Coulston, 1996), which is included in the supporting documentation provided alongside the data download (called IG.pdf).

\subsection{Spittle bugs}

Populations of Philaenus spumarius and Neophilaenus lineatus were monitored annually at the majority of the ECN terrestrial sites. In mid-June, counts of the spittle produced by nymphs were made in 20 quadrats $\left(0.25 \mathrm{~m}^{2}\right)$ randomly placed near the TSS. Also, in late August, the proportions of each colour morph of the adult $P$. spumarius were estimated using sweep netting on the TSS when the weather conditions were dry. Colour polymorphism is likely to be environmentally determined (Whittaker, 1965) and therefore an indicator of environmental change. The samples were collected annually (nymphs in June and adults in August). A count of each species and colour morph was recorded. Full operating procedures are provided in the protocol document (Whittaker, 1996), which is included in the supporting documentation provided alongside the data download (called IS.pdf).

\subsection{Baseline vegetation}

This was a one-off survey at the start of ECN monitoring to establish a vegetation map at all sites. It allowed a vegetation map to be generated and the plots for continuous monitoring (see Sect. 2.12, 2.13, 2.14) to be selected. An approximately regular grid, coincident with the UK National Grid, was superimposed on the site map, scaled so as to provide approximately 400 sample grid positions. This ensured the plot locations were unbiased and relocatable. Additionally, no more than 100 points (infill points) were chosen to ensure all vegetation types were represented. A $2 \mathrm{~m} \times 2 \mathrm{~m}$ plot was centred on each grid and infill point, oriented using magnetic bearings. These plots were permanently marked (the plot corners are marked with buried metal stakes). Species presence was recorded in the plots. Where the plots fell in woodland, the trees and shrubs were recorded in a $10 \mathrm{~m} \times 10 \mathrm{~m}$ plot centred on the $2 \mathrm{~m} \times 2 \mathrm{~m}$ plot to provide a more representative sample of the canopy and understory. Full operating procedures are provided in the protocol document (Rodwell et al., 1996), which is included in the supporting documentation provided alongside the data download (called V.pdf).

\subsection{Coarse-grain vegetation}

A random selection was made of 40 of the $2 \mathrm{~m} \times 2 \mathrm{~m}$ plots from the regular grid set-up for baseline survey vegetation recording (Sect. 2.11) at the majority of the ECN terrestrial sites at the onset of ECN monitoring. Where infill plots were included in the baseline survey, up to 10 of these plots were also randomly selected, providing a total of up to 50 of these plots for coarse-grain monitoring. The plots were permanently marked. Where plots fell in woodland or scrub, the associated woodland protocol was also undertaken (see Sect. 2.13). The protocol was undertaken every 9 years. Species presence was recorded in each of the twenty-five $40 \mathrm{~cm} \times 40 \mathrm{~cm}$ cells within the plots. Full operating procedures are provided in the protocol document (Rodwell et al., 1996), which is included in the supporting documentation provided alongside the data download (called V.pdf).

\subsection{Woodland vegetation}

Where grid and infill plots selected for coarse-grain sampling (Sect. 2.12) fall in scrub or woodland, $10 \mathrm{~m} \times 10 \mathrm{~m}$ plots (which were centred on the $2 \mathrm{~m} \times 2 \mathrm{~m}$ plot used in the coarsegrain survey) were used to record trees and shrubs. Species dominance was assessed within the plots. A total of 10 cells, each $40 \mathrm{~cm} \times 40 \mathrm{~cm}$, were selected at random within the plot and marked. Seedlings were counted by species in each cell. Additionally, an individual tree was chosen nearest the centre point of the cell and monitored for height and diameter at breast height (dbh). The protocol was undertaken every 9 years, but dbh was measured every 3 years for sites where there was woodland. The variables recorded are listed in Table 6. Full operating procedures are provided in the protocol document (Rodwell et al., 1996), which is included in the supporting documentation provided alongside the data download (called V.pdf).

\subsection{Fine-grain vegetation}

At least two $10 \mathrm{~m} \times 10 \mathrm{~m}$ plots from each vegetation type present at the site were randomly selected (from the plots selected in the baseline survey (see Sect. 2.11). The plots were chosen to coincide with the original grid and infill plots where possible but otherwise were selected using randomly selected pairs of co-ordinates. The plots did not coincide with the coarse-grain sampling plots (see Sect. 2.12) to avoid repeated disturbance to the plots. Ten $40 \mathrm{~cm} \times 40 \mathrm{~cm}$ cells were selected randomly within these plots. This survey was under- 
Table 6. Woodland vegetation variables.

\begin{tabular}{lll}
\hline Name in dataset & Description & Units \\
\hline A & Species recorded as sapling & species code \\
C & Species recorded as canopy dominant & species code \\
DIAMETER & Diameter at breast height (dbh) & $\mathrm{cm}$ \\
DISTANCE & Distance of stem from centre of random cell & $\mathrm{m}$ \\
E & Species recorded as seedling & species code \\
H & Species recorded as shrub layer & species code \\
HEIGHT & Height & m \\
I & Species recorded as intermediate & species code \\
NUM_STEMS & Number of stems & count \\
S & Species recorded as subdominant & species code \\
SEEDLING & Species recorded in seedling survey of cell & species code \\
U & Species recorded as suppressed & species code \\
Q1-n & Quality code (see Sect. 4) & integer \\
\hline
\end{tabular}

taken every 3 years, but some sites chose to do this survey annually to provide a better temporal range. The same plots were visited on each occasion, but often a smaller number of plots were chosen to do the annual survey. Species presence was recorded within the cells. Full operating procedures are provided in the protocol document (Rodwell et al., 1996), which is included in the supporting documentation provided alongside the data download (called V.pdf).

\subsection{Frogs}

It is difficult to monitor populations of adult frogs; therefore, phenological observations were made of selected pools and ditches, and the number of egg masses were assessed as an indicator of the "health" of frog populations at sites with standing water present. Additionally, a $250 \mathrm{~mL}$ water sample was taken from the spawning area and analysed. The time at which frog breeding starts in the UK varies greatly; therefore, observations of frog behaviour were made at the appropriate time for each site. The variables recorded are listed in Table 7 . Full operating procedures are provided in the protocol document (Beattie et al., 1996), which is included in the supporting documentation provided alongside the data download (called BF.pdf).

\subsection{Birds - breeding bird survey}

Bird species were recorded on two transect lines (within a $1 \mathrm{~km}$ square) at the majority of the ECN sites. Counts were made in the morning, ideally no later than 09:00 UTC. Transects were walked, at a slow and methodical pace, when the visibility was good and there was no strong wind or heavy rain. All birds that were seen or heard, as well as their distance (there are four distance categories) from the transect were recorded. The methodology used was that of the Breeding Birds Survey (BBS, 2019) organised by the British Trust for Ornithology (BTO). The transect was walked twice each year (once between April and mid-May and the second between mid-May to late June). Full operating procedures are provided in the protocol document (Sykes, 1996a), which is included in the supporting documentation provided alongside the data download (called BB.pdf).

This protocol replaced the Common Bird Census (see Sect. 2.17) in 1999. The methodologies of the two surveys are different, thus it is unfortunately not possible to create a single time series from both datasets. Please also note that the Breeding Birds Survey is designed to be a national-scale survey, therefore the site-based ECN data are limited in the amount of information that they can provide on the precise relationships between population levels and environmental change. It is recommended that the ECN data are used in conjunction with data from more widespread monitoring programmes (i.e. those of the BTO) so these limitations can be mitigated.

\subsection{Birds - common bird census}

Bird species were recorded in a plot that was, ideally, a minimum of 40 ha in farmland and 10 ha in woodland. The methodology used was that of the Common Birds Census (CBC, 2019) organised by the BTO. A total of 10 visits were made between mid-March and late June, spaced evenly through the season. Cold, windy and wet days were avoided. The CBC uses a mapping method in which a series of visits were made to all parts of a defined plot during the breeding season and contacts with birds by sight or sound were recorded on large-scale maps. Information from the series of visits was combined to estimate the number of territories found. Within the $\mathrm{CBC}$ protocol, some species were also monitored by nest counts on the plot or by a combination of nest counts and territory estimation. Full operating procedures are provided in the protocol document (Sykes, 1996b), which is included in the supporting documentation provided alongside the data download (called BC.pdf). 
Table 7. Frog variables.

\begin{tabular}{|c|c|c|}
\hline Name in dataset & Description & Units \\
\hline ALKY & Alkalinity & $\mathrm{mg} \mathrm{L}^{-1}$ \\
\hline ALUMINIUM & Aluminium & $\mathrm{mg} \mathrm{L}^{-1}$ \\
\hline CALCIUM & Calcium & $\mathrm{mg} \mathrm{L}^{-1}$ \\
\hline CHLORIDE & Chloride & $\mathrm{mg} \mathrm{L}^{-1}$ \\
\hline CONDY & Conductivity & $\mu \mathrm{S} \mathrm{cm}^{-1}$ \\
\hline COLOUR & Absorbance at $436 \mathrm{nM}$ & $\mathrm{nM}$ \\
\hline CONGDATE & Date frogs first seen congregating & date \\
\hline DEPTH & Depth at centre of spawning area & $\mathrm{cm}$ \\
\hline DOC & Dissolved organic carbon & $\mathrm{mg} \mathrm{L}^{-1}$ \\
\hline HATCHDATE & Date of first hatching observed & date \\
\hline IRON & Iron & $\mathrm{mg} \mathrm{L}^{-1}$ \\
\hline LEAVEDATE & Date frogs first seen leaving & date \\
\hline MAGNESIUM & Magnesium & $\mathrm{mg} \mathrm{L}^{-1}$ \\
\hline MAXTMP & Maximum temperature & ${ }^{\circ} \mathrm{C}$ \\
\hline MINTMP & Minimum temperature & ${ }^{\circ} \mathrm{C}$ \\
\hline NEWMASS & Number of new spawn masses & count \\
\hline NH4N & Ammonium & $\mathrm{mg} \mathrm{L}^{-1}$ \\
\hline $\mathrm{NO} 3 \mathrm{~N}$ & Nitrate nitrogen & $\mathrm{mg} \mathrm{L}^{-1}$ \\
\hline PERCDEAD & Percentage dead or diseased eggs & $\%$ \\
\hline $\mathrm{PH}$ & $\mathrm{pH}$ from water sample processed in laboratory & $\mathrm{pH}$ scale $1-14$ \\
\hline PH1 & First $\mathrm{pH}$ reading from daily sample & pH scale $1-14$ \\
\hline $\mathrm{PH} 2$ & Second $\mathrm{pH}$ reading from daily sample & $\mathrm{pH}$ scale $1-14$ \\
\hline PH3 & Third $\mathrm{pH}$ reading from daily sample & $\mathrm{pH}$ scale $1-14$ \\
\hline PHAQCS & Aquacheck system pH stirred & $\mathrm{pH}$ scale $1-14$ \\
\hline PHAQCU & Aquacheck system $\mathrm{pH}$ unstirred & $\mathrm{pH}$ scale $1-14$ \\
\hline PO4P & Phosphate phosphorus & $\mathrm{mg} \mathrm{L}^{-1}$ \\
\hline POTASSIUM & Potassium & $\mathrm{mg} \mathrm{L}^{-1}$ \\
\hline $\mathrm{SO} 4 \mathrm{~S}$ & Sulfate sulfur & $\mathrm{mg} \mathrm{L}^{-1}$ \\
\hline SODIUM & Sodium & $\mathrm{mg} \mathrm{L}^{-1}$ \\
\hline SPAWNDATE & Date of first spawning observed & date \\
\hline SURFAREA & Total surface area covered by spawn & $\mathrm{m}^{2}$ \\
\hline STAGE & Stage reading of water level & $\mathrm{mm}$ \\
\hline TOTALN & Total nitrogen & $\mathrm{mg} \mathrm{L}^{-1}$ \\
\hline TOTALP & Total dissolved phosphorus & $\mathrm{mg} \mathrm{L}^{-1}$ \\
\hline VACUUM & Residual vacuum at time of sampling & bar \\
\hline VOLUME & Volume of sample collected & $\mathrm{mL}$ \\
\hline Q1-n & Quality code (see Sect. 4) & integer \\
\hline
\end{tabular}

The CBC was the standard protocol at lowland ECN sites until 1999 when it was replaced by the BBS (see Sect. 2.16). The methodologies of the two surveys are different so it is unfortunately not possible to create a single time series from both datasets. A few sites continued the $\mathrm{CBC}$ alongside the BBS for a few years to allow for a comparison. Additionally, historical data (pre-ECN) was obtained for the Wytham site. Therefore, the date ranges for individual sites in this dataset are not consistent. As with the BBS, the $\mathrm{CBC}$ was designed to be a national-scale survey, thus similar limitations apply to the site-based ECN data provided in this dataset.

\subsection{Bats}

Bat species were mapped (using a bat detector) and their behaviour recorded at the majority of the ECN sites. One or more kilometre-sized squares were selected at the site. This selection did not need to be random as long as the square was reasonably typical of the site and that fieldwork could be conducted safely at night. The square was divided into two and a transect selected through each of these half squares. The methodology was based on that used in the Bats and Habitats survey organised for the Joint Nature Conservation Committee (Walsh et al., 1995). The transect was walked four times in each year (once in each 3-week period between June and September). Bat detectors were used during the sur- 
vey and the frequency of the detector was tuned to could be altered during the survey if that helped ensure all species were recorded (in particular to distinguish between Pipistrellus species). Surveys were not carried out when rain was heavy or there were strong winds. A count of each species observed and their behaviour was recorded. Full operating procedures are provided in the protocol document (Walsh et al., 1996), which is included in the supporting documentation provided alongside the data download (called BA.pdf).

The methodology is somewhat limited in the amount of information that it can provide about the precise relationships between population levels and environmental change. Nevertheless, by linking the ECN results to those from more widespread monitoring programmes, these limitations can be mitigated.

\subsection{Rabbits and deer}

There were no practicable methods of making direct measures of the population size of the rabbit and deer populations; therefore, an index method based on dropping counts was used to estimate relative abundance at the majority of the ECN sites. The butterfly monitoring transect was used. A second transect that covered habitat types not present on the butterfly transect was also selected. Dropping counts were recorded on a transect twice a year (once in late March and again in late September). Droppings on the transect were cleared 2 weeks before sampling took place. At Moor House, the same methodology was also used to estimate the relative abundance of grouse. Full operating procedures are provided in the protocol document (Coulson, 1996), which is included in the supporting documentation provided alongside the data download (called BU.pdf).

\section{Datasets}

The ECN datasets are listed in Table 2, together with their citation information, the frequency of measurement and the variables collected. The NERC Environmental Information Data Centre (the repository that hosts the datasets) provides data and supporting information as separate packages - this allows improvements to be made to the supporting documentation over time if necessary while maintaining a persistent, citable dataset. The DOI for each dataset links to a landing page that contains separate links to download the data and the supporting information.

Each dataset follows the same basic structure:

- SITECODE - site code (see Table 1);

- SDATE - date of sampling;

- FIELDNAME - the variable being measured (these are described below and in the supporting information);

- VALUE - the value of the measured variable.
All the datasets have this structure in common but some of the datasets may also contain some additional information where necessary for the measurement. This is fully documented in the supporting information. For the majority of datasets, the entire time period is included in the data download; however, two large datasets are split into yearly time slices to make downloading easier for the user (see Sect. 3.1 and 3.3)

The supporting information, i.e. the protocol document, supplementary data and quality information, is provided with each dataset. It is important to refer to this information prior to analysing the data. The supporting information is provided in a zip file using the "supporting information" link on the relevant page for each dataset (Rennie et al., 2016a, b, 2017a-p, 2018). All the zip files contain a document called ***_DATA_STRUCTURE.doc (where *** is the ECN measurement code; see Table 2). This document contains detailed information about the structure of the dataset, location information for the sites, information about the variables measured, and documents for any additional information needed to understand the dataset and provides any coding lists used.

Some usage notes are included below.

\subsection{Meteorology}

Given the size of this dataset, the data have been split into yearly csv files. Users are advised to open these files in a text editor or to use a statistical package to analyse these data as the file sizes remain too large for a software package like Excel to open.

Over the period of data collection, the majority of the ECN sites have operated more than one AWS in the same location - e.g. when kit is replaced. In many cases, these have been run concurrently to enable cross-checking of data. Replacement AWSs are indicated by the "AWSNO" field in the dataset - these are ID numbers assigned sequentially. Users should be aware of the AWSNO when analysing the data particularly when two AWSs have been run concurrently to avoid misleading results by inadvertently combining data from two AWSs.

\subsection{Soil solution chemistry}

Where samples were combined, this is indicated in the data with the replicate IDs XXS (combined shallow samplers) and XXD (combined deep samplers) in the datasets. Occasionally, the suction samplers were replaced, this is indicated in the data with a new replicate ID.

\subsection{Surface water discharge}

Given the size of this dataset, the data have been split into yearly csv files. Users are advised to open these files in a text editor or use a statistical package to analyse these data as the 
file sizes remain too large for a software package like Excel to open.

One site (Moor House - Upper Teesdale) uses an Environment Agency logger to record water discharge. The Environment Agency uses the WISKI format to record these data (the Hydrolog format was used prior to 2004). Both of these formats include quality information that is available in this dataset (for Moor House only). An explanation for these quality codes is provided in the supporting information.

\subsection{Carabid beetles}

There is an additional data column in this dataset that applies to only one species (Pterostichus madidus), where additional information was collected on gender ( $\mathrm{M}$ or $\mathrm{F}$ ) and leg colour (red, R, and black, B). The ratio of leg colour is thought to depend on ecological factors (Terrell-Nield, 1992).

\subsection{Standards and coding lists}

The ECN forms part of a global system of long-term, integrated environmental research networks; see Sect. 5 for more details. Therefore, it primarily uses the LTER-Europe controlled vocabulary, EnvThes (EnvThes, 2019), as the basis for the semantic harmonisation of data with its European and International partners. The ECN uses a number of coding lists within its datasets. Where possible, existing coding systems were used to maintain compatibility with other related data resources. The coding lists used by the ECN are listed in Table 8 . These coding lists are fully documented in the supporting information.

\subsection{Dataset completeness}

The majority of the ECN sites have been collecting the full suite of ECN measurements since 1993 but two sites joined the network later - Yr Wyddfa (Snowdon) in 1995 and Cairngorms in 1999. However, it should be noted that many of the sites are in remote locations, which means that site managers are occasionally unable to attend the sites for health and safety reasons, causing gaps in the dataset. In particular, there was a foot-and-mouth disease outbreak in the UK in 2001, which meant a number of the sites could not be visited for biosecurity reasons and that the data for that year are patchy. In addition, Rothamsted ceased biological monitoring in 2011 and Drayton left the network in 2014.

\section{Data quality}

Quality control is central to all stages of ECN data collection and management and is handled through a number of steps.

\subsection{Standard operating procedures}

As described in the Sect. 2, data collection procedures were co-ordinated and standardised across the sites through published protocols.

\subsection{Data transfer templates}

Data were checked and formatted by data providers prior to being submitted by email (in standardised, comma-separated files). Detailed data transfer documentation for each protocol guided the preparation of these files to ensure comparability of data across sites and over time. This documentation includes rules for handling missing values and data quality information. To aid site managers, a bespoke set of data entry templates were developed for each protocol, using MS Access, to improve data handling efficiency (Rennie, 2016). These templates incorporate quality-checking procedures and help to ensure that quality-checked, standardised and formatted data were submitted by site managers. The design of the templates takes into account ease of use, with the main emphasis being on minimising error. This type of data entry software is particularly useful where numeric coding systems for species are in use; numbers are less memorable and mistakes in one digit of a code can produce serious errors. For example, the software uses drop-down lists of codes (which are dynamically linked with a list of the species names) so that the codes can be cross-checked against the species name to ensure that the correct code is chosen.

\subsection{Data verification}

In addition to the checks made in the templates, standard verification procedures were applied to all data before import into the database. The procedures performed numeric range checks (i.e. checking if a value falls within a specified range), categorical checks (e.g. checking that a species code appears on the standard code list), formatting (i.e. that the dataset conforms to the specified data format) and logical integrity checks (i.e. checking the data make sense, e.g. that the dates in one dataset match those in a related dataset). Appropriate range settings for ECN variables were selected following discussion with specialists in each field. These ranges are held in a table in the database and the data are checked against this before being committed to the database. Where values fell outside these ranges, a cautious approach was adopted towards discarding data on the principle that apparent errors could be valid outliers. Data values identified by validation software as "out of range" were treated in one of three ways.

- Where values were clearly meaningless due to a known cause (e.g. an instrumentation fault that could not be back-corrected), the data were discarded and database fields set to null (no data), and quality flags were added to the database. 
Table 8. Species coding lists.

\begin{tabular}{lll}
\hline ECN measurement & Coding list used & Reference \\
\hline Moths (IM) & Rothamsted Insect Survey & Rothamsted Insect Survey (2019) \\
Butterflies (IB) & Butterfly Monitoring Scheme & UKBMS (2019) \\
Carabid beetles (IG) & Biological Records Centre & Biological Records Centre (2019) \\
Spittle bugs (IS) & Biological Records Centre & Biological Records Centre (2019) \\
Vegetation (VB, VC, VW, VF) & National Vegetation Classification. & Rodwell (1991) \\
& A look-up to the Biological Records Centre & Biological Records Centre (2019) \\
& codes is also provided & \\
Birds (CBC) & British Trust for Ornithology & BBS (2019) \\
Birds (CBC) & British Trust for Ornithology & CBC (2019) \\
Bats (BA) & Code list developed in-house & Supporting information with the data download \\
Rabbit and deer (BU) & Code list developed in-house & Supporting information with the data download \\
\hline
\end{tabular}

- Where values were clearly in error, or out of range due to known calibration errors and could be backcorrected, the data were corrected (these changes were flagged in the database).

- Where there was no straightforward explanation for outliers, the data were stored in the database, accompanied by quality flags (see Sect. 4.4).

\subsection{Quality flagging}

The ECN site managers assigned quality codes to indicate factors that may affect the quality of the data being collected, including deviations from the protocol, faulty instrumentation and common problems. They picked these from a standard list of ECN quality codes; these quality codes are included in the data download, and an explanation for the codes is provided in the supporting documentation. Site managers could pick as many quality codes as were applicable. Occasionally, an unusual event took place that was not covered by these codes. In that case, the site manager attached text explaining the circumstances. This is indicated by a quality code "999" in the data download. This quality text is available in a file called ECN_***_qtext.csv (where *** is the measurement code; see Table 2), which is provided in the supporting documentation.

\subsection{Quality assessment exercises}

Samples were kept where possible (e.g. archived invertebrate samples), meaning the accuracy of identification can be assessed at a later date if necessary. Occasionally, quality assessment exercises have been run by appropriate experts to check, for example, consistency in species identification across sites (Scott and Hallam, 2003). The quality of more ephemeral measurements such as meteorology or water quality can only be similarly assessed by running duplicate or parallel systems. Duplicate systems are expensive, and in practice assessment normally involved regular checks for instrument drift and recorder error. Where possible, when new instrumentation or methods needed to be introduced, new and old systems were run in parallel to assess their relationship. This is assessed by the individual site manager, who must satisfy themselves that the new systems compare well before proceeding with the switchover.

\section{ECN datasets in context}

The ECN is nationally unique with its focus on highfrequency and co-located measurements. It provides a rare opportunity to link pressures and responses to investigate relationships between environmental variables and explore environmental change over significant timescales. The data included within these datasets have been the focus of a number of peer-reviewed scientific publications over the past 20 years. For example, linking meteorological data with invertebrate species data for exploring the impact of drought (Morecroft et al., 2002), exploring trends in the physical and biological environment (Morecroft et al., 2009), determining that hydrochloric acid deposition was a driver of UK soil acidification (Evans et al., 2011), and investigating declines in carabid beetle biodiversity (Brooks et al., 2012). Many of the datasets were incorporated in papers forming a journal special issue marking the first 20 years of the ECN (Sier and Monteith, 2016b). This special issue demonstrates how effective the datasets are in assessing and interpreting environmental change, covering a breadth of topics, such as trends in weather and atmospheric deposition (Monteith et al., 2016); trends in dissolved organic carbon (Sawicka et al., 2016; Moody et al., 2016); various aspects of change in UK plant communities (Rose et al., 2016; Morecroft et al., 2016; Pallett et al., 2016; Milligan et al., 2016), ecosystem services (Dick et al., 2016), and carabid beetle communities (Eyre et al., 2016; Pozsgai et al., 2016); the use of digital imaging to assess vegetation cover (Baxendale et al., 2016); and the response of Lepidoptera communities to warming (Martay et al., 2016). A full catalogue of the peer-reviewed papers that have used ECN data are available on the website (ECN Publications Catalogue, 2019). 
ECN sites cover a wide range of UK habitats but, given their focus on high-frequency data, are costly to run and are relatively few in number. The representativeness of ECN sites was compared to data obtained by the UK Countryside Survey (CS - Countryside Survey, 2019). The survey is based on a stratified random sample of $1 \mathrm{~km}$ squares from the intersections of a regular $15 \mathrm{~km}$ grid superimposed on the rural areas of Great Britain. Analysis revealed that the British ECN sites effectively span the range of values for both temperature and rainfall and cover a similar range of vegetation types to the CS, with the exception of arable, a land use category not assessed at ECN sites but present on several sites (Dick et al., 2011).

ECN sites contribute to a number of national monitoring programmes, e.g. Rothamsted Insect Survey (Rothamsted Insect Survey, 2019), Countryside Survey (Countryside Survey, 2019), the UK Butterfly Monitoring Scheme (UKBMS, 2019), the Breeding Bird Survey (BBS, 2019), the United Kingdom Eutrophying and Acidifying Network (UKEAP, 2019), and the Cosmic-ray Soil Moisture Monitoring Network (COSMOS-UK, 2019). The ECN's focus on multidisciplinary, co-located measurements can help integrate these networks and provides temporal-scale context for observations made by these networks, for example by providing information on year to year variation in vegetation communities to help inform how CS data can be influenced by weather variability (Scott et al., 2010).

The ECN is formally recognised as the UK's contribution to a global system of long-term, integrated environmental research networks and is a member of LTER-Europe (the European Long-Term Ecosystem Research Network - Mirtl, 2010) and ILTER (International Long-Term Ecological Research - Kim, 2006). Individual ECN sites are also involved in other international networks, including INTERACT (International Network for Terrestrial Research and Monitoring in the Arctic - INTERACT, 2019), GLORIA (Global Observation Research Initiative in Alpine Environments - GLORIA, 2019), ICP Forest Level II (ICP Forests, 2019) and FLUXNET (FLUXNET, 2019).

\section{Data availability}

Provision of easy access to data has always been central to the ECN's strategy to provide a resource for environmental research, policy purposes and public information. The ECN datasets are hosted by the NERC Environmental Information Data Centre (EIDC, 2019) managed by the UK Centre for Ecology and Hydrology (UKCEH). The EIDC manages nationally important terrestrial and freshwater science datasets and is a CoreTrustSeal accredited data repository. EIDC has a registration system - users need a free account to download data. The ECN datasets can be discovered and downloaded through the EIDC's data catalogue (the Environmental Information Platform, EIP). The datasets are listed in Table 2, together with their citation information. They should be cited for every use using the information provided (Rennie et al., 2016a, b, 2017a-p, 2018).

The ECN datasets are available under the Open Government Licence (Open Government Licence, 2019), and they are available as comma-separated files. Temporal extensions, provided as additional time slices, to the datasets will be created as further data become available.

\section{Conclusions}

The datasets collected by the UK Environmental Change Network are an invaluable and nationally unique resource, which, over the years, has proved useful to a range of users, including the scientific community and national policy makers. The co-location of high-frequency meteorological, biological and biogeochemical measurements means the ECN datasets are ideally placed for the development of clearer process understanding and assessing the impact of shorter-term events, such as droughts, on ecosystems. This 2-decade ECN data record provides a long-term baseline of environmental variability across a wide range of UK habitats against which environmental changes can be assessed.

Author contributions. SR was responsible for the management of the ECN Data Centre, publication of the datasets and led the writing of this paper. CA, SA, DB, SB, VB, JD, BD, CM, DP, RR, SMS, TS, CT and HW are the current site managers and are responsible for site management, data collection and quality checking. All co-authors contributed to the writing, discussion and review of this paper.

Competing interests. The authors declare that they have no conflict of interest.

Acknowledgements. The ECN programme is sponsored by a consortium of UK government departments and agencies who contribute to the programme through funding either site monitoring or network co-ordination activities: Agri-Food and Biosciences Institute, Biotechnology and Biological Sciences Research Council, Cyfoeth Naturiol Cymru - Natural Resources Wales, Defence Science \& Technology Laboratory, Department for Environment, Food and Rural Affairs, Environment Agency, Forestry Commission, Llywodraeth Cymru - Welsh Government, Natural England, Natural Environment Research Council, Northern Ireland Environment Agency, Scottish Environment Protection Agency, the Scottish Government, and Scottish Natural Heritage. The following people were ECN site managers during the period of data collection of these datasets: John Adamson, Roy Anderson, Chris Andrews, Sarah Atkinson, John Bater, Neil Bayfield, Clive Bealey, Katy Beaton, Deb Beaumont, Sue Benham, Vic Bowmaker, Chris Britt, Rob Brooker, David Brooks, Andrew Brunt, Jacqui Brunt, Sam Clawson, Gordon Common, Richard Cooper, Stuart Corbett, Nigel Critchley, Peter Dennis, Jan Dick, Bev Dodd, Nikki 
Dodd, Neil Donovan, Jonathan Easter, Edward Eaton, Mel Flexen, Andy Gardiner, Dave Hamilton, Paul Hargreaves, Maggie HattonEllis, Mark Howe, Olly Howells, Jana Kahl, Simon Langan, Dylan Lloyd, Mathieu Lundy, Briege McCarney, Yvonne McElarney, Colm McKenna, Simon McMillan, Frank Milne, Linda Milne, Mike Morecroft, Matt Murphy, Allison Nelson, Harry Nicholson, Denise Pallett, Dafydd Parry, Imogen Pearce, Gabor Pozsgai, Adrian Riley, Rob Rose, Stefanie Schäfer, Tony Scott, Chris Shortall, Phil Smith, Roger Smith, Richard Tait, Carol Taylor, Michele Taylor, Maddie Thurlow, Christine Tilbury, Alex Turner, Ken Tyson, Helen Watson, Mike Whittaker, Matthew Wilkinson, Ian Woiwod and Christopher Wood. ECN and its Data Centre are co-ordinated by the Central Co-ordination Unit at UKCEH Lancaster. The following people have been involved in this during the period of data collection of these datasets: John Adamson, Chris Benefield, Deirdre Caffrey, Bill Heal, Pete Henrys, Lynne Irvine, Mandy Lane, Don Monteith, Mike Morecroft, Terry Parr, Susannah Rennie, Rob Rose, Andy Scott, Lorna Sherrin, Andy Sier, Ian Simpson and Mike Sykes.

Financial support. ECN co-ordination was supported by the Natural Environment Research Council, through UKCEH (grant no. NEC06397). Site work at Rothamsted and North Wyke was funded by Biotechnology and Biological Sciences Research Council (BBS/E/C/000J0300).

Review statement. This paper was edited by Kirsten Elger and reviewed by Øystein Godoy and Johannes Peterseil.

\section{References}

Adamson, J. K.: Initial water handling, in: The United Kingdom Environmental Change Network: Protocols for standard measurements at terrestrial sites, edited by: Sykes, J. M. and Lane, A. M. J., The Stationery Office (London), 145-148, 1996a.

Adamson, J. K.: Soil solution chemistry, in: The United Kingdom Environmental Change Network: Protocols for standard measurements at terrestrial sites, edited by: Sykes, J. M. and Lane, A. M. J., The Stationery Office (London), 75-86, $1996 \mathrm{~b}$.

Adamson, J. K. and Sykes, J. M.: Precipitation chemistry, in: The United Kingdom Environmental Change Network: Protocols for standard measurements at terrestrial sites, edited by: Sykes, J. M. and Lane, A. M. J., The Stationery Office (London), 53-59, 1996.

Baxendale, C., Ostle, N. J., Wood, C. M., Oakley, S., and Ward, S. E.: Can digital image classification be used as a standardised method for surveying peatland vegetation cover?, Ecol. Indic., 68, 150-156, https://doi.org/10.1016/j.ecolind.2015.11.035, 2016.

BBS (Breeding Bird Survey): available at: https://www.bto.org/ volunteer-surveys/bbs, last access: 15 April 2019.

Beattie, B. C., Adamson, J. K., and Sykes, J. M.: Frog spawn, in: The United Kingdom Environmental Change Network: Protocols for standard measurements at terrestrial sites, edited by: Sykes, J. M. and Lane, A. M. J., The Stationery Office (London), 141-144, 1996.
Biological Records Centre: available at: https://www.brc.ac.uk/, last access: 15 November 2019.

Bojanic, D., Adamson, J. K., Rowland, A. P., and Sykes, J. M.: Atmospheric chemistry, in: The United Kingdom Environmental Change Network: Protocols for standard measurements at terrestrial sites, edited by: Sykes, J. M. and Lane, A. M. J., The Stationery Office (London), 47-52, 1996.

Brooks, D. R., Bater, J. E., Clark, S. J., Monteith, D. T., Andrews, C., Corbett, S. J., Beaumont, D. A., and Chapman, J. W.: Large carabid beetle declines in a United Kingdom monitoring network increases evidence for a widespread loss in insect biodiversity, J. Appl. Ecol., 49, 1009-1019, https://doi.org/10.1111/j.13652664.2012.02194.x, 2012.

Burt, T. P. and Johnson, R. C.: Meteorology - automatic weather station and standard meteorological observations, in: The United Kingdom Environmental Change Network: Protocols for standard measurements at terrestrial sites, edited by: Sykes, J. M. and Lane, A. M. J., The Stationery Office (London), 37-46, 1996.

CBC (Common Bird Census): available at: https://www.bto.org/ about-birds/birdtrends/2011/methods/common-birds-census, last access: 15 April 2019.

COSMOS-UK (Cosmic-ray Soil Moisture Monitoring Network): available at: https://cosmos.ceh.ac.uk/, last access: 15 April 2019.

Coulson, J. C.: Rabbits and deer, in: The United Kingdom Environmental Change Network: Protocols for standard measurements at terrestrial sites, edited by: Sykes, J. M. and Lane, A. M. J., The Stationery Office (London), 139-140, 1996.

Countryside Survey: available at: https://countrysidesurvey.org.uk/, last access: 15 April 2019.

Dick, J., Andrews, C., Beaumont, D. A., Benham, S., Brooks, D. R., Corbett, S., Lloyd, D., McMillan, S., Monteith, D. T., Pilgrim, E. S., Rose, R., Scott, A., Scott, T., Smith, R. I., Taylor, C., Taylor, M., Turner, A., and Watson, H.: A comparison of ecosystem services delivered by 11 long-term monitoring sites in the UK environmental change network, Environmetrics, 22, 639-648, https://doi.org/10.1002/env.1069, 2011.

Dick, J., Andrews, C., Beaumont, D. A., Benham, S., Dodd, N., Pallett, D., Rose, R., Scott, T., Smith, R. I., Schäfer, S. M., Turner, A., and Watson, H.: Analysis of temporal change in delivery of ecosystem services over 20 years at long term monitoring sites of the UK Environmental Change Network, Ecol. Indic., 68, 115125, https://doi.org/10.1016/j.ecolind.2016.02.021, 2016.

Environmental Change Network: available at: http://www.ecn.ac. uk, last access: 15 April 2019.

ECN Data Centre: available at: http://data.ecn.ac.uk, last access: 15 April 2019.

ECN Publications Catalogue: available at: http://data.ecn.ac.uk/ PRU/pru.asp, last access: 15 April 2019.

EIDC: available at: http://eidc.ceh.ac.uk/, last access: 15 April 2019.

EnvThes: available at: http://vocabs.lter-europe.net/edg/tbl/ EnvThes.editor, last access: 29 July 2019.

Evans, C. D., Monteith, D. T., Fowler, D., Cape, J. N., and Brayshaw, S.: Hydrochloric acid: an overlooked driver of environmental change Environ. Sci. Technol., 45, 1887-1894, https://doi.org/10.1021/es103574u, 2011.

Eyre, M. D., McMillan, S. D., Critchley, C. N. R.: Ground beetles (Coleoptera, Carabidae) as indicators of change and pattern in 
the agroecosystem: longer surveys improve understanding, Ecol. Indic., 68, 82-88, https://doi.org/10.1016/j.ecolind.2015.11.009, 2016.

FLUXNET: available at: https://fluxnet.fluxdata.org/, last access: 15 April 2019.

GLORIA (Global Observation Research Initiative in Alpine Environments): available at: https://gloria.ac.at/, last access: 15 April 2019.

ICP Forest: available at: http://icp-forests.net/, last access: 15 April 2019.

INTERACT (International Network for Terrestrial Research and Monitoring in the Arctic): available at: https://eu-interact.org/, last access: 15 April 2019.

Johnson, R. C. and Burt, T. P.: Surface water chemistry and quality, in: The United Kingdom Environmental Change Network: Protocols for standard measurements at terrestrial sites, edited by: Sykes, J. M. and Lane, A. M. J., The Stationery Office (London), 64-65, 1996a.

Johnson, R. C. and Burt, T. P.: Surface water discharge, in: The United Kingdom Environmental Change Network: Protocols for standard measurements at terrestrial sites, edited by: Sykes, J. M. and Lane, A. M. J., The Stationery Office (London), 60-62, 1996b.

Kim, E. S.: Development, potentials, and challenges of the International Long-Term Ecological Research (ILTER) Network, Ecol. Res., 21, 788-793, https://doi.org/10.1007/s11284-006-0049-1, 2006.

Martay, B., Monteith, D. T., Brewer, M. J., Brereton, T., Shortall, C. R., and Pearce-Higgins, J. W.: An indicator highlights seasonal variation in the response of Lepidoptera communities to warming, Ecol. Indic., 6, 126-133, https://doi.org/10.1016/j.ecolind.2016.01.057, 2016.

Meteorological Office: Observer's handbook, 4th Edn., HMSO (London), 1982.

Milligan, G., Rose, R., and Marrs, R. H.: Winners and losers in a long-term study of vegetation change at Moor House NNR: effects of sheep-grazing and its removal on British upland vegetation, Ecol. Indic., 68, 89-101, https://doi.org/10.1016/j.ecolind.2015.10.053, 2016.

Mirtl, M.: Introducing the next generation of ecosystem research in Europe: LTER-Europe's multi-functional and multi-scale approach, edited by: Müller, F., Baessler, C., Schubert, H., and Klotz, S., Long-Term Ecological Research, Springer, Netherlands, 75-93, https://doi.org/10.1007\%2F978-90-481-8782-9_6, 2010.

Mirtl, M., Borer, E. T., Djukic, I., Forsius, M., Haubold, H., Hugo, W., Jourdan, J., Lindenmayer, D., McDowell, W. H., Muraoka, H., Orenstein, D. E., Pauw, J. C., Peterseil, J., Shibata, H., Wohner, C., Yu, X., and Haase, P.: Genesis, goals and achievements of long-term ecological research at the global scale: a critical review of ILTER and future directions, Sci. Total Environ., 626, 1439-1462, https://doi.org/10.1016/j.scitotenv.2017.12.001, 2018.

Monteith, D. T., Henrys, P. A., Banin, L., Smith, R. I., Morecroft, M. D., Scott, T., Andrews, C., Beaumont, D. A., Benham, S., Bowmaker, V., Corbett, S., Dick, J., Dodd, B., Dodd, N., McKenna, C., McMillan, S. D., Pallett, D., Pereira, G., Rennie, S. C., Rose, R., Schäfer, S. M., Sherrin, L., Turner A., Watson, H., Poskitt, J., and Tang, S. Y.: Trends and variabil- ity in weather and atmospheric deposition at UK Environmental Change Network sites (1993-2012), Ecol. Indic., 68, 21-35, https://doi.org/10.1016/j.ecolind.2016.01.061, 2016.

Moody, C. S., Worrall, F., and Burt, T. P.: Identifying DOC gains and losses during a 20-year record in the Trout Beck catchment, Moor House, UK, Ecol. Indic., 68, 102-114, https://doi.org/10.1016/j.ecolind.2015.11.033, 2016.

Morecroft, M. D., Bealey, C. E., Howells, O., Rennie, S., and Woiwod, I.: Effects of drought on contrasting insect and plant species in the UK in the mid-1990s, Global Ecol. Biogeogr., 11, 7-22, https://doi.org/10.1046/j.1466-822X.2002.00174.x, 2002.

Morecroft, M. D., Bealey, C. E., Beaumont, D. A., Benham, S., Brooks, D. R., Burt, T. P., Critchley, C. N. R., Dick, J., Littlewood, N. A., Monteith, D. T., Scott, W. A., Smith, R. I., Walmsley, C., and Watson, H.: The UK Environmental Change Network: Emerging trends in the composition of plant and animal communities and the physical environment, Biol. Conserv., 142, 2814-2832, https://doi.org/10.1016/j.biocon.2009.07.004, 2009.

Morecroft, M. D., Bealey, C. E., Taylor, M. E., and Scott, W. A.: Interannual variability, stability and resilience in UK plant communities, Ecol. Indic., 68, 63-72, https://doi.org/10.1016/j.ecolind.2015.11.040, 2016.

Open Government Licence: available at: http://www. nationalarchives.gov.uk/doc/open-government-licence/version/ 3/, last access: 15 April 2019.

Pallett, D., Pescott, O. L., and Schäfer, S. M.: Changes in plant species richness and productivity in response to decreased nitrogen inputs in grassland in southern England, Ecol. Indic., 68, 73-81, https://doi.org/10.1016/j.ecolind.2015.12.024, 2016.

Pozsgai, G., Baird, J., Littlewood, N. A., Pakeman, R. J., and Young, M. R.: Interspecific networks in ground beetle (Coleoptera: Carabidae) assemblages, Ecol. Indic., 68, 134-141, https://doi.org/10.1016/j.ecolind.2015.11.031, 2016.

Rennie, S.: Providing information on environmental change: Data management, discovery and access in the UK Environmental Change Network Data Centre, Ecol. Indic., 68, 13-20, https://doi.org/10.1016/j.ecolind.2016.01.060, 2016.

Rennie, S., Adamson, J., Anderson, R., Andrews, C., Bater, J., Bayfield, N., Beaton, K., Beaumont, D., Benham, S., Bowmaker, V., Britt, C., Brooker, R., Brooks, D., Brunt, J., Common, G., Cooper, R., Corbett, S., Critchley, N., Dennis, P., Dick, J., Dodd, B., Dodd, N., Donovan, N., Easter, J., Eaton, E., Flexen, M., Gardiner, A., Hamilton, D., Hargreaves, P., Hatton-Ellis, M., Howe, M., Kahl, J., Lane, M., Langan, S., Lloyd, D., McElarney, Y., McKenna, C., McMillan, S., Milne, F., Milne, L., Morecroft, M., Murphy, M., Nelson, A., Nicholson, H., Pallett, D., Parry, D., Pearce, I., Pozsgai, G., Rose, R., Schafer, S., Scott, T., Sherrin, L., Shortall, C., Smith, R., Smith, P., Tait, R., Taylor, C., Taylor, M., Thurlow, M., Turner, A., Tyson, K., Watson, H., and Whittaker, M.: UK Environmental Change Network (ECN) baseline vegetation data: 1991-2000, NERC Environmental Information Data Centre, https://doi.org/10.5285/a7b49ac1-24f5-406e-ac8f3d05fb583e3b, 2016a.

Rennie, S., Adamson, J., Anderson, R., Andrews, C., Bater, J., Bayfield, N., Beaton, K., Beaumont, D., Benham, S., Bowmaker, V., Britt, C., Brooker, R., Brooks, D., Brunt, J., Common, G., Cooper, R., Corbett, S., Critchley, N., Dennis, P., Dick, J., Dodd, B., Dodd, N., Donovan, N., Easter, J., Eaton, E., Flexen, M., Gardiner, A., Hamilton, D., Hargreaves, P., Hatton-Ellis, M., Howe, 
M., Kahl, J., Lane, M., Langan, S., Lloyd, D., McElarney, Y., McKenna, C., McMillan, S., Milne, F., Milne, L., Morecroft, M., Murphy, M., Nelson, A., Nicholson, H., Pallett, D., Parry, D., Pearce, I., Pozsgai, G., Rose, R., Schafer, S., Scott, T., Sherrin, L., Shortall, C., Smith, R., Smith, P., Tait, R., Taylor, C., Taylor, M., Thurlow, M., Turner, A., Tyson, K., Watson, H., and Whittaker, M.: UK Environmental Change Network (ECN) coarse grain vegetation data: 1993-2012, NERC Environmental Information Data Centre, https://doi.org/10.5285/d349babc329a-4d6e-9eca-92e630e1be3f, 2016 b.

Rennie, S., Adamson, J., Anderson, R., Andrews, C., Bater, J., Bayfield, N., Beaton, K., Beaumont, D., Benham, S., Bowmaker, V., Britt, C., Brooker, R., Brooks, D., Brunt, J., Common, G., Cooper, R., Corbett, S., Critchley, N., Dennis, P., Dick, J., Dodd, B., Dodd, N., Donovan, N., Easter, J., Eaton, E., Flexen, M., Gardiner, A., Hamilton, D., Hargreaves, P., Hatton-Ellis, M., Howe, M., Kahl, J., Lane, M., Langan, S., Lloyd, D., McCarney, B., McElarney, Y., McKenna, C., McMillan, S., Milne, F., Milne, L., Morecroft, M., Murphy, M., Nelson, A., Nicholson, H., Pallett, D., Parry, D., Pearce, I., Pozsgai, G., Rose, R., Schafer, S., Scott, T., Sherrin, L., Shortall, C., Smith, R., Smith, P., Tait, R., Taylor, C., Taylor, M., Thurlow, M., Turner, A., Tyson, K., Watson, H., Whittaker, M., Wilkinson, M., and Wood, C.: UK Environmental Change Network (ECN) meteorology data: 1991-2015, NERC Environmental Information Data Centre, https://doi.org/10.5285/fc9bcd1c-e3fc-4c5a-b5692fe62d40f2f5, 2017a.

Rennie, S., Adamson, J., Anderson, R., Andrews, C., Bater, J., Bayfield, N., Beaton, K., Beaumont, D., Benham, S., Bowmaker, V., Britt, C., Brooker, R., Brooks, D., Brunt, J., Common, G., Cooper, R., Corbett, S., Critchley, N., Dennis, P., Dick, J., Dodd, B., Dodd, N., Donovan, N., Easter, J., Flexen, M., Gardiner, A., Hamilton, D., Hargreaves, P., Hatton-Ellis, M., Howe, M., Kahl, J., Lane, M., Langan, S., Lloyd, D., McCarney, B., McElarney, Y., McKenna, C., McMillan, S., Milne, F., Milne, L., Morecroft, M., Murphy, M., Nelson, A., Nicholson, H., Pallett, D., Parry, D., Pearce, I., Pozsgai, G., Rose, R., Schafer, S., Scott, T., Sherrin, L., Shortall, C., Smith, R., Smith, P., Tait, R., Taylor, C., Taylor, M., Thurlow, M., Turner, A., Tyson, K., Watson, H., Whittaker, M., and Wood, C.: UK Environmental Change Network (ECN) atmospheric nitrogen chemistry data: 1993-2015, NERC Environmental Information Data Centre, https://doi.org/10.5285/baf51776-c2d0-4e57-9cd330cd6336d9cf, 2017b.

Rennie, S., Adamson, J., Anderson, R., Andrews, C., Bater, J., Bayfield, N., Beaton, K., Beaumont, D., Benham, S., Bowmaker, V., Britt, C., Brooker, R., Brooks, D., Brunt, J., Common, G., Cooper, R., Corbett, S., Critchley, N., Dennis, P., Dick, J., Dodd, B., Dodd, N., Donovan, N., Easter, J., Flexen, M., Gardiner, A., Hamilton, D., Hargreaves, P., Hatton-Ellis, M., Howe, M., Kahl, J., Lane, M., Langan, S., Lloyd, D., McCarney, B., McElarney, Y., McKenna, C., McMillan, S., Milne, F., Milne, L., Morecroft, M., Murphy, M., Nelson, A., Nicholson, H., Pallett, D., Parry, D., Pearce, I., Pozsgai, G., Rose, R., Schafer, S., Scott, T., Sherrin, L., Shortall, C., Smith, R., Smith, P., Tait, R., Taylor, C., Taylor, M., Thurlow, M., Turner, A., Tyson, K., Watson, H., Whittaker, M., and Wood, C.: UK Environmental Change Network (ECN) precipitation chemistry data: 1992-2015, NERC Environmen- tal Information Data Centre, https://doi.org/10.5285/18b7c387037d-4949-98bc-e8db5ef4264c, 2017c.

Rennie, S., Adamson, J., Anderson, R., Andrews, C., Bater, J., Bayfield, N., Beaton, K., Beaumont, D., Benham, S., Bowmaker, V., Britt, C., Brooker, R., Brooks, D., Brunt, J., Common, G., Cooper, R., Corbett, S., Critchley, N., Dennis, P., Dick, J., Dodd, B., Dodd, N., Donovan, N., Easter, J., Flexen, M., Gardiner, A., Hamilton, D., Hargreaves, P., Hatton-Ellis, M., Howe, M., Kahl, J., Lane, M., Langan, S., Lloyd, D., McCarney, B., McElarney, Y., McKenna, C., McMillan, S., Milne, F., Milne, L., Morecroft, M., Murphy, M., Nelson, A., Nicholson, H., Pallett, D., Parry, D., Pearce, I., Pozsgai, G., Rose, R., Schafer, S., Scott, T., Sherrin, L., Shortall, C., Smith, R., Smith, P., Tait, R., Taylor, C., Taylor, M., Thurlow, M., Turner, A., Tyson, K., Watson, H., Whittaker, M., and Wood, C.: UK Environmental Change Network (ECN) soil solution chemistry data: 1992-2015, NERC Environmental Information Data Centre, https://doi.org/10.5285/b330d39568f2-47f1-8d59-3291dc02923b, 2017d.

Rennie, S., Adamson, J., Anderson, R., Andrews, C., Bater, J., Bayfield, N., Beaton, K., Beaumont, D., Benham, S., Bowmaker, V., Britt, C., Brooker, R., Brooks, D., Brunt, J., Common, G., Cooper, R., Corbett, S., Critchley, N., Dennis, P., Dick, J., Dodd, B., Dodd, N., Donovan, N., Easter, J., Flexen, M., Gardiner, A., Hamilton, D., Hargreaves, P., Hatton-Ellis, M., Howe, M., Kahl, J., Lane, M., Langan, S., Lloyd, D., McCarney, B., McElarney, Y., McKenna, C., McMillan, S., Milne, F., Milne, L., Morecroft, M., Murphy, M., Nelson, A., Nicholson, H., Pallett, D., Parry, D., Pearce, I., Pozsgai, G., Rose, R., Schafer, S., Scott, T., Sherrin, L., Shortall, C., Smith, R., Smith, P., Tait, R., Taylor, C., Taylor, M., Thurlow, M., Turner, A., Tyson, K., Watson, H., Whittaker, M., and Wood, C.: UK Environmental Change Network (ECN) stream water chemistry data: 1992-2015, NERC Environmental Information Data Centre, https://doi.org/10.5285/fd7ca5ef-460a463c-ad2b-5ad48bb4e22e, 2017e.

Rennie, S., Adamson, J., Anderson, R., Andrews, C., Bater, J., Bayfield, N., Beaton, K., Beaumont, D., Benham, S., Bowmaker, V., Britt, C., Brooker, R., Brooks, D., Brunt, J., Common, G., Cooper, R., Corbett, S., Critchley, N., Dennis, P., Dick, J., Dodd, B., Dodd, N., Donovan, N., Easter, J., Flexen, M., Gardiner, A., Hamilton, D., Hargreaves, P., Hatton-Ellis, M., Howe, M., Kahl, J., Lane, M., Langan, S., Lloyd, D., McElarney, Y., McKenna, C., McMillan, S., Milne, F., Milne, L., Morecroft, M., Murphy, M., Nelson, A., Nicholson, H., Pallett, D., Parry, D., Pearce, I., Pozsgai, G., Rose, R., Schafer, S., Scott, T., Sherrin, L., Shortall, C., Smith, R., Smith, P., Tait, R., Taylor, C., Taylor, M., Thurlow, M., Turner, A., Tyson, K., Watson, H., Whittaker, M., and Wood, C.: UK Environmental Change Network (ECN) stream water discharge data: 1993-2015, NERC Environmental Information Data Centre, https://doi.org/10.5285/8b58c86b-0c2a-4d48-b25a7a0141859004, 2017f.

Rennie, S., Adamson, J., Anderson, R., Andrews, C., Bater, J., Bayfield, N., Beaton, K., Beaumont, D., Benham, S., Bowmaker, V., Britt, C., Brooker, R., Brooks, D., Brunt, J., Common, G., Cooper, R., Corbett, S., Critchley, N., Dennis, P., Dick, J., Dodd, B., Dodd, N., Donovan, N., Easter, J., Flexen, M., Gardiner, A., Hamilton, D., Hargreaves, P., Hatton-Ellis, M., Howe, M., Kahl, J., Lane, M., Langan, S., Lloyd, D., McCarney, B., McElarney, Y., McKenna, C., McMillan, S., Milne, F., Milne, L., Morecroft, M., Murphy, M., Nelson, A., Nichol- 
son, H., Pallett, D., Parry, D., Pearce, I., Pozsgai, G., Riley, A., Rose, R., Schafer, S., Scott, T., Sherrin, L., Shortall, C., Smith, R., Smith, P., Tait, R., Taylor, C., Taylor, M., Thurlow, M., Turner, A., Tyson, K., Watson, H., Whittaker, M., Woiwod, I., and Wood, C.: UK Environmental Change Network (ECN) moth data: 1992-2015, NERC Environmental Information Data Centre, https://doi.org/10.5285/a2a49f47-49b3-46daa434-bb22e524c5d2, 2017g.

Rennie, S., Adamson, J., Anderson, R., Andrews, C., Bater, J., Bayfield, N., Beaton, K., Beaumont, D., Benham, S., Bowmaker, V., Britt, C., Brooker, R., Brooks, D., Brunt, J., Common, G., Cooper, R., Corbett, S., Critchley, N., Dennis, P., Dick, J., Dodd, B., Dodd, N., Donovan, N., Easter, J., Flexen, M., Gardiner, A., Hamilton, D., Hargreaves, P., Hatton-Ellis, M., Howe, M., Kahl, J., Lane, M., Langan, S., Lloyd, D., McCarney, B., McElarney, Y., McKenna, C., McMillan, S., Milne, F., Milne, L., Morecroft, M., Murphy, M., Nelson, A., Nicholson, H., Pallett, D., Parry, D., Pearce, I., Pozsgai, G., Rose, R., Schafer, S., Scott, T., Sherrin, L., Shortall, C., Smith, R., Smith, P., Tait, R., Taylor, C., Taylor, M., Thurlow, M., Tilbury, C., Turner, A., Tyson, K., Watson, H., Whittaker, M., and Wood, C.: UK Environmental Change Network (ECN) butterfly data: 1993-2015, NERC Environmental Information Data Centre, https://doi.org/10.5285/5aeda581b4f2-4e51-b1a6-890b6b3403a3, 2017h.

Rennie, S., Adamson, J., Anderson, R., Andrews, C., Bater, J., Bayfield, N., Beaton, K., Beaumont, D., Benham, S., Bowmaker, V., Britt, C., Brooker, R., Brooks, D., Brunt, J., Common, G., Cooper, R., Corbett, S., Critchley, N., Dennis, P., Dick, J., Dodd, B., Dodd, N., Donovan, N., Easter, J., Flexen, M., Gardiner, A., Hamilton, D., Hargreaves, P., Hatton-Ellis, M., Howe, M., Kahl, J., Lane, M., Langan, S., Lloyd, D., McElarney, Y., McKenna, C., McMillan, S., Milne, F., Milne, L., Morecroft, M., Murphy, M., Nelson, A., Nicholson, H., Pallett, D., Parry, D., Pearce, I., Pozsgai, G., Rose, R., Schafer, S., Scott, T., Sherrin, L., Shortall, C., Smith, R., Smith, P., Tait, R., Taylor, C., Taylor, M., Thurlow, M., Tilbury, C., Turner, A., Tyson, K., Watson, H., Whittaker, M., and Wood, C.: UK Environmental Change Network (ECN) carabid beetle data: 1992-2015, NERC Environmental Information Data Centre, https://doi.org/10.5285/8385f864-dd41-410f-b248028f923cb281, $2017 \mathrm{i}$.

Rennie, S., Adamson, J., Anderson, R., Andrews, C., Bater, J., Bayfield, N., Beaton, K., Beaumont, D., Benham, S., Bowmaker, V., Britt, C., Brooker, R., Brooks, D., Brunt, J., Common, G., Cooper, R., Corbett, S., Critchley, N., Dennis, P., Dick, J., Dodd, B., Dodd, N., Donovan, N., Easter, J., Flexen, M., Gardiner, A., Hamilton, D., Hargreaves, P., Hatton-Ellis, M., Howe, M., Kahl, J., Lane, M., Langan, S., Lloyd, D., McElarney, Y., McKenna, C., McMillan, S., Milne, F., Milne, L., Morecroft, M., Murphy, M., Nelson, A., Nicholson, H., Pallett, D., Parry, D., Pearce, I., Pozsgai, G., Rose, R., Schafer, S., Scott, T., Sherrin, L., Shortall, C., Smith, R., Smith, P., Tait, R., Taylor, C., Taylor, M., Thurlow, M., Turner, A., Tyson, K., Watson, H., Whittaker, M., and Wood, C.: UK Environmental Change Network (ECN) woodland vegetation data: 1993-2014, NERC Environmental Information Data Centre, https://doi.org/10.5285/94aef007-634e-42db-bc529aae86adbd33, 2017j.

Rennie, S., Adamson, J., Anderson, R., Andrews, C., Bater, J., Bayfield, N., Beaton, K., Beaumont, D., Benham, S., Bowmaker, V., Britt, C., Brooker, R., Brooks, D., Brunt, J., Common, G.,
Cooper, R., Corbett, S., Critchley, N., Dennis, P., Dick, J., Dodd, B., Dodd, N., Donovan, N., Easter, J., Flexen, M., Gardiner, A., Hamilton, D., Hargreaves, P., Hatton-Ellis, M., Howe, M., Kahl, J., Lane, M., Langan, S., Lloyd, D., McElarney, Y., McKenna, C., McMillan, S., Milne, F., Milne, L., Morecroft, M., Murphy, M., Nelson, A., Nicholson, H., Pallett, D., Parry, D., Pearce, I., Pozsgai, G., Rose, R., Schafer, S., Scott, T., Sherrin, L., Shortall, C., Smith, R., Smith, P., Tait, R., Taylor, C., Taylor, M., Thurlow, M., Turner, A., Tyson, K., Watson, H., Whittaker, M., and Wood, C.: UK Environmental Change Network (ECN) fine grain vegetation data: 1994-2015, NERC Environmental Information Data Centre, https://doi.org/10.5285/b98efec8-6de0-4e0c-85dcfe4cdf01f086, 2017k.

Rennie, S., Adamson, J., Anderson, R., Andrews, C., Bater, J., Bayfield, N., Beaton, K., Beaumont, D., Benham, S., Bowmaker, V., Britt, C., Brooker, R., Brooks, D., Brunt, J., Common, G., Cooper, R., Corbett, S., Critchley, N., Dennis, P., Dick, J., Dodd, B., Dodd, N., Donovan, N., Easter, J., Flexen, M., Gardiner, A., Hamilton, D., Hargreaves, P., Hatton-Ellis, M., Howe, M., Kahl, J., Lane, M., Langan, S., Lloyd, D., McCarney, B., McElarney, Y., McKenna, C., McMillan, S., Milne, F., Milne, L., Morecroft, M., Murphy, M., Nelson, A., Nicholson, H., Pallett, D., Parry, D., Pearce, I., Pozsgai, G., Rose, R., Schafer, S., Scott, T., Sherrin, L., Shortall, C., Smith, R., Smith, P., Tait, R., Taylor, C., Taylor, M., Thurlow, M., Turner, A., Tyson, K., Watson, H., Whittaker, M., and Wood, C.: UK Environmental Change Network (ECN) frog data: 1994-2015, NERC Environmental Information Data Centre, https://doi.org/10.5285/4d8c7dd9-8248-46cab988-c1fc38e51581, 20171.

Rennie, S., Adamson, J., Anderson, R., Andrews, C., Bater, J., Bayfield, N., Beaton, K., Beaumont, D., Benham, S., Bowmaker, V., Britt, C., Brooker, R., Brooks, D., Brunt, A., Brunt, J., Clawson, S., Common, G., Cooper, R., Corbett, S., Critchley, N., Dennis, P., Dick, J., Dodd, B., Dodd, N., Donovan, N., Easter, J., Flexen, M., Gardiner, A., Hamilton, D., Hargreaves, P., Hatton-Ellis, M., Howe, M., Kahl, J., Lane, M., Langan, S., Lloyd, D., McElarney, Y., McKenna, C., McMillan, S., Milne, F., Milne, L., Morecroft, M., Murphy, M., Nelson, A., Nicholson, H., Pallett, D., Parry, D., Pearce, I., Pozsgai, G., Rose, R., Schafer, S., Scott, T., Sherrin, L., Shortall, C., Smith, R., Smith, P., Tait, R., Taylor, C., Taylor, M., Thurlow, M., Turner, A., Tyson, K., Watson, H., Whittaker, M., and Wood, C.: UK Environmental Change Network (ECN) bird data: 1995-2015, NERC Environmental Information Data Centre, https://doi.org/10.5285/5886c3ba-1fa5-49c0-8da840e69a10d2b5, 2017m.

Rennie, S., Bater, J., Beaumont, D., Benham, S., Britt, C., Brooks, D., Brunt, A., Brunt, J., Corbett, S., Critchley, N., Donovan, N., Hargreaves, P., Howe, M., Lane, M., McMillan, S., Morecroft, M., Onley, D., Overall, R., Pallett, D., Schafer, S., Scott, T., Sherrin, L., Shortall, C., Smith, R., Smith, P., Taylor, M., and Tyson, K.: UK Environmental Change Network (ECN) common breeding birds data 1971-2007, NERC Environmental Information Data Centre, https://doi.org/10.5285/8582a02c-b28c-45d2afa1-c1e85fba023d, 2017n.

Rennie, S., Adamson, J., Anderson, R., Andrews, C., Bater, J., Bayfield, N., Beaton, K., Beaumont, D., Benham, S., Bowmaker V., Britt, C., Brooker, R., Brooks, D., Brunt, J., Common, G., Cooper, R., Corbett, S., Critchley, N., Dennis, P., Dick, J., Dodd, B., Dodd, N., Donovan, N., Easter, J., Flexen, M., Gardiner, A., 
Hamilton, D., Hargreaves, P., Hatton-Ellis, M., Howe, M., Kahl, J., Lane, M., Langan, S., Lloyd, D., Lundy, M., McElarney, Y., McKenna, C., McMillan, S., Milne, F., Milne, L., Morecroft, M., Murphy, M., Nelson, A., Nicholson, H., Pallett, D., Parry, D., Pearce, I., Pozsgai, G., Rose, R., Schafer, S., Scott, T., Sherrin, L., Shortall, C., Smith, R., Smith, P., Tait, R., Taylor, C., Taylor, M., Thurlow, M., Turner, A., Tyson, K., Watson, H., Whittaker, M., and Wood, C.: UK Environmental Change Network (ECN) bat data: 1993-2015, NERC Environmental Information Data Centre, https://doi.org/10.5285/2588ee91-6cbd-4888-86fc81858d1bf085, 2017o.

Rennie, S., Adamson, J., Anderson, R., Andrews, C., Bater, J., Bayfield, N., Beaton, K., Beaumont, D., Benham, S., Bowmaker, V., Britt, C., Brooker, R., Brooks, D., Brunt, J., Common, G., Cooper, R., Corbett, S., Critchley, N., Dennis, P., Dick, J., Dodd, B., Dodd, N., Donovan, N., Easter, J., Flexen, M., Gardiner, A., Hamilton, D., Hargreaves, P., Hatton-Ellis, M., Howe, M., Kahl, J., Lane, M., Langan, S., Lloyd, D., McCarney, B., McElarney, Y., McKenna, C., McMillan, S., Milne, F., Milne, L., Morecroft, M., Murphy, M., Nelson, A., Nicholson, H., Pallett, D., Parry, D., Pearce, I., Pozsgai, G., Rose, R., Schafer, S., Scott, T., Sherrin, L., Shortall, C., Smith, R., Smith, P., Tait, R., Taylor, C., Taylor, M., Thurlow, M., Turner, A., Tyson, K., Watson, H., Whittaker, M., and Wood, C.: UK Environmental Change Network (ECN) rabbit and deer data: 1993-2015, NERC Environmental Information Data Centre, https://doi.org/10.5285/0be0aed3f205-4f1f-a65d-84f8cfd8d50f, 2017p.

Rennie, S., Adamson, J., Anderson, R., Andrews, C., Bater, J., Bayfield, N., Beaton, K., Beaumont, D., Benham, S., Bowmaker, V., Britt, C., Brooker, R., Brooks, D., Brunt, J., Common, G., Cooper, R., Corbett, S., Critchley, N., Dennis, P., Dick, J., Dodd, B., Dodd, N., Donovan, N., Easter, J., Flexen, M., Gardiner, A., Hamilton, D., Hargreaves, P., Hatton-Ellis, M., Howe, M., Kahl, J., Lane, M., Langan, S., Lloyd, D., McElarney, Y., McKenna, C., McMillan, S., Milne, F., Milne, L., Morecroft, M., Murphy, M., Nelson, A., Nicholson, H., Pallett, D., Parry, D., Pearce, I., Pozsgai, G., Rose, R., Schafer, S., Scott, T., Sherrin, L., Shortall, C., Smith, R., Smith, P., Tait, R., Taylor, C., Taylor, M., Thurlow, M., Tilbury, C., Turner, A., Tyson, K., Watson, H., Whittaker, M., and Wood, C.: UK Environmental Change Network (ECN) spittle bug data: 1993-2015, NERC Environmental Information Data Centre, https://doi.org/10.5285/aff433be-0869-4393-b7659e6faad2a12b, 2018.

Rodwell, J. S.: British plant communities, Cambridge University Press, 1991.

Rodwell, J. S., Sykes, J. M., and Helps, M. B: Vegetation, in: The United Kingdom Environmental Change Network: Protocols for standard measurements at terrestrial sites, edited by: Sykes, J. M. and Lane, A. M. J., The Stationery Office (London), 87-100, 1996.

Rose, R., Monteith, D. T., Henrys, P. A., Smart, S. M., Wood, C. M., Morecroft, M., Andrews, C., Beaumont, D. A., Benham, S., Bowmaker, V., Corbett, S., Dick, J., Dodd, B., Dodd, N., Flexen, M., McKenna, C., McMillan, S. D., Pallett, D., Rennie, S. C., Schäfer, S. M., Scott, T., Sherrin, L., Turner, A., and Watson, H.: Evidence for increases in vegetation species richness across UK Environmental Change Network sites linked to changes in air pollution and weather patterns, Ecol. Indic., 68, 52-62, https://doi.org/10.1016/j.ecolind.2016.01.005, 2016.
Rothamsted Insect Survey: available at: http://www.rothamsted.ac. uk/insect-survey, last access: 15 April 2019.

Rowland, A. P.: Analytical guidelines for water samples, in: The United Kingdom Environmental Change Network: Protocols for standard measurements at terrestrial sites, edited by: Sykes, J. M. and Lane, A. M. J., The Stationery Office (London), 149-153, 1996.

Sawicka, K., Monteith, D. T., Vanguelova, E. I., Wade, A. J., and Clark, J. M.: Fine-scale temporal characterization of trends in soil water dissolved organic carbon and potential drivers, Ecol. Indic., 68, 36-51, https://doi.org/10.1016/j.ecolind.2015.12.028, 2016.

Scott, W. A. and Hallam, C. J.: Assessing species misidentification rates through quality assurance of vegetation monitoring, Plant Ecol., 165, 101-115, https://doi.org/10.1023/A:1021441331839, 2003.

Scott, W. A., Morecroft, M. D., Taylor, M. E., and Smart, S. M.: Countryside Survey - Environmental Change Network Link, CS Technical Report, No. 6/07, available at: http://www.countrysidesurvey.org.uk/sites/default/files/CS_

UK_2007_TR6\%20-\%20ECN\%20report.pdf (last access: 11/04/2019), 2010.

Sier, A. and Monteith, D.: The UK Environmental Change Network after twenty years of integrated ecosystem assessment: Key findings and future perspectives, Ecol. Indic., 68, 1-12, https://doi.org/10.1016/j.ecolind.2016.02.008, 2016a.

Sier, A. and Monteith, D. (Eds.): Assessing ecosystem resilience through Long Term Ecosystem Research: observations from the first twenty years of the UK Environmental Change Network, Ecol. Indic, 68, 1-156, available at: https://www.sciencedirect. com/journal/ecological-indicators/vol/68/suppl/C (last access: 11 April 2019), 2016b.

Sykes, J. M.: Breeding birds, in: The United Kingdom Environmental Change Network: Protocols for standard measurements at terrestrial sites, edited by: Sykes, J. M. and Lane, A. M. J., The Stationery Office (London), 131-133, 1996a.

Sykes, J. M.: Common breeding birds, in: The United Kingdom Environmental Change Network: Protocols for standard measurements at terrestrial sites, edited by: Sykes, J. M. and Lane, A. M. J., The Stationery Office (London), 125-127, 1996b.

Sykes, J. M. and Lane, A. M. J. (Eds.): The UK Environmental Change Network: Protocols for standard measurements at terrestrial sites, The Stationery Office (London), 1996.

Terrell-Nield, C. E.: Distribution of leg-colour morphs of Pterostichus madidus (F.) in relation to climate, in: The role of ground beetles in ecological and environmental studies, edited by: Stork, N., Intercept Ltd, Andover, Hampshire, 39-51, 1992.

UKBMS (United Kingdom Butterfly Monitoring Scheme): available at: http://www.ukbms.org/, last access: 15 April 2019.

UKEAP (United Kingdom Eutrophying and Acidifying Network): available at: https://uk-air.defra.gov.uk/networks/network-info? view=ukeap, last access: 15 April 2019.

Walsh, A. L., Harris, S., and Hutson, A. M.: Abundance and habitat selection of foraging vespertilionid bats in Britain: a landscapescale approach, Symp. Zool. Soc. Lond, 67, 325-344, 1995.

Walsh, A. L., Harris, S., and Hutson, A. H.: Bats, in: The United Kingdom Environmental Change Network: Protocols for standard measurements at terrestrial sites, edited by: Sykes, J. M. and Lane, A. M. J., The Stationery Office (London), 134-138, 1996. 
Whittaker, J. B.: The distribution and population dynamics of Neophilaenus lineatus (L.) and N. exclamationis (Thun.) (Homoptera: Cercopidae) on Pennine moorland, J. Anim. Ecol., 34, 277-297, 1965.

Whittaker, J. B.: Spittle bugs, in: The United Kingdom Environmental Change Network: Protocols for standard measurements at terrestrial sites, edited by: Sykes, J. M. and Lane, A. M. J., The Stationery Office (London), 111-117, 1996.

Wohner, C., Peterseil, J., Poursanidis, D., Kliment, T., Wilson, M., Mirtl, M., and Chrysoulakis, N.: DEIMS-SDR - A web portal to document research sites and their associated data, Ecol. Inform., 51, 15-24, https://doi.org/10.1016/j.ecoinf.2019.01.005, 2019.
Woiwod, I. P.: Moths, in: The United Kingdom Environmental Change Network: Protocols for standard measurements at terrestrial sites, edited by: Sykes, J. M. and Lane, A. M. J., The Stationery Office (London), 104-108, 1996a.

Woiwod, I. P.: Butterflies, in: The United Kingdom Environmental Change Network: Protocols for standard measurements at terrestrial sites, edited by: Sykes, J. M. and Lane, A. M. J., The Stationery Office (London), 109-110, 1996b.

Woiwod, I. P. and Coulson, J. C.: Ground predators, in: The United Kingdom Environmental Change Network: Protocols for standard measurements at terrestrial sites, edited by: Sykes, J. M. and Lane, A. M. J., The Stationery Office (London), 118-121, 1996. 